\title{
Fire in ice: two millennia of boreal forest fire history from the Greenland NEEM ice core
}

\author{
P. Zennaro ${ }^{1,2}$, N. Kehrwald ${ }^{1}$, J. R. McConnell ${ }^{3}$, S. Schüpbach ${ }^{1,4}$, O. J. Maselli ${ }^{3}$, J. Marlon ${ }^{5}$, P. Vallelonga ${ }^{6,7}$, \\ D. Leuenberger ${ }^{4}$, R. Zangrando ${ }^{2}$, A. Spolaor ${ }^{1}$, M. Borrotti ${ }^{1,8}$, E. Barbaro ${ }^{1}$, A. Gambaro ${ }^{1,2}$, and C. Barbante ${ }^{1,2,9}$ \\ ${ }^{1}$ Ca'Foscari University of Venice, Department of Environmental Science, Informatics and Statistics, Santa Marta - Dorsoduro \\ 2137, 30123 Venice, Italy \\ ${ }^{2}$ Institute for the Dynamics of Environmental Processes, IDPA-CNR, Dorsoduro 2137, 30123 Venice, Italy \\ ${ }^{3}$ Desert Research Institute, Department of Hydrologic Sciences, 2215 Raggio Parkway, Reno, NV 89512, USA \\ ${ }^{4}$ Climate and Environmental Physics, Physics Institute and Oeschger Centre for Climate Change Research, University of \\ Bern, Sidlerstrasse 5, 3012 Bern, Switzerland \\ ${ }^{5}$ Yale School of Forestry and Environmental Studies, 195 Prospect Street, New Haven, CT 06511, USA \\ ${ }^{6}$ Centre for Ice and Climate, Niels Bohr Institute, University of Copenhagen, Juliane Maries Vej 30, Copenhagen $\varnothing 2100$ \\ Denmark \\ ${ }^{7}$ Department of Imaging and Applied Physics, Curtin University, Kent St, Bentley, WA 6102, Australia \\ ${ }^{8}$ European Centre for Living Technology, San Marco 2940, 30124 Venice, Italy \\ ${ }^{9}$ Centro B. Segre, Accademia Nazionale dei Lincei, 00165 Rome, Italy
}

Correspondence to: P. Zennaro (piero@unive.it)

Received: 30 January 2014 - Published in Clim. Past Discuss.: 28 February 2014

Revised: 15 September 2014 - Accepted: 16 September 2014 - Published: 29 October 2014

\begin{abstract}
Biomass burning is a major source of greenhouse gases and influences regional to global climate. Pre-industrial fire-history records from black carbon, charcoal and other proxies provide baseline estimates of biomass burning at local to global scales spanning millennia, and are thus useful to examine the role of fire in the carbon cycle and climate system. Here we use the specific biomarker levoglucosan together with black carbon and ammonium concentrations from the North Greenland Eemian (NEEM) ice cores $\left(77.49^{\circ} \mathrm{N}, 51.2^{\circ} \mathrm{W} ; 2480 \mathrm{~m}\right.$ a.s.1) over the past 2000 years to infer changes in boreal fire activity. Increases in boreal fire activity over the periods 1000-1300 CE and decreases during 700-900 CE coincide with high-latitude NH temperature changes. Levoglucosan concentrations in the NEEM ice cores peak between 1500 and $1700 \mathrm{CE}$, and most levoglucosan spikes coincide with the most extensive central and northern Asian droughts of the past millennium. Many of these multi-annual droughts are caused by Asian monsoon failures, thus suggesting a connection between low- and high-latitude climate processes. North America is a primary source of biomass burning aerosols due to its relative prox-
\end{abstract}

imity to the Greenland Ice Cap. During major fire events, however, isotopic analyses of dust, back trajectories and links with levoglucosan peaks and regional drought reconstructions suggest that Siberia is also an important source of pyrogenic aerosols to Greenland.

\section{Introduction}

Fire influences regional and global climate through the emission of greenhouse gases and particulates that reflect and absorb incoming solar radiation (Ramanathan and Carmichael, 2008; Bowman et al., 2009; IPCC, 2013). Biomass burning plays an important role in the carbon cycle, as it emits up to $50 \%$ as much $\mathrm{CO}_{2}$ as fossil fuel combustion (Bowman et al., 2009). Fire products such as black carbon (BC) have a radiative absorption forcing up to $55 \%$ of that of $\mathrm{CO}_{2}$ and a greater influence than other greenhouse gas forcings, including methane $\left(\mathrm{CH}_{4}\right)$, chlorofluorocarbons, nitrous oxide and tropospheric ozone (Ramanathan and Carmichael, 2008; Jacobson, 2004; van der Werf et al., 2004; Running, 2006; 
McConnell et al., 2007). Combined direct and indirect effects rank $\mathrm{BC}$ as the second-largest contributor to globally averaged positive radiative forcing since the pre-industrial period (Ramanathan and Carmichael, 2008; Randerson et al., 2006). Estimates of the radiative forcing of combined biomass burning aerosols are still not well defined. Biomass burning may have a short-term (10 years) net negative forcing on global climate, where long-lived greenhouse gasses may then cancel the cooling after decades (100 years) (Jacobson, 2004). The 5th IPCC report suggests a net radiative forcing of $+0.00 \pm 0.20 \mathrm{~W} \mathrm{~m}^{-2}$ (IPCC, 2013) due to biomass burning; however, human activities may have also changed the net radiative forcing of pre-industrial fires (Ward et al., 2012).

Fire influences the climate system, but in turn centennialscale Holocene fire variations are influenced by climate (Marlon et al., 2013; Power et al., 2008). Precipitation decreases fuel flammability (Pechony and Shindell, 2010), but biomass burning is highest at intermediate moisture levels (Daniau et al., 2012); a balance must therefore be struck between climatic conditions that are wet enough to allow biomass to grow but dry enough to allow combustion (Pyne, 2001). Increased temperatures and atmospheric $\mathrm{CO}_{2}$ permit greater plant productivity and could result in greater fuel availability and hence increased fire activity (Marlon et al., 2008; Daniau et al., 2010). Human activities have also had an influence on biomass burning trends (Marlon et al., 2008) through deforestation and slash-and-burn agricultural practices (FAO, 2007) - practices which may have affected fire regimes during the entire past millennia (Bowman et al., 2009; Kaplan et al., 2011; Ruddiman, 2003). The observable impact of humans on fire regimes differs by geographic region (McWethy et al., 2009; Marlon et al., 2012; Power et al., 2008), but, over the course of the 20th century, human activity has begun to influence the global fire regime more than natural causes (Marlon et al., 2008; Pechony and Shindell, 2010).

\subsection{Boreal forest fires}

The circumpolar boreal zone contains about $30 \%$ of world's forests, with half of the world's forest carbon and about $30 \%$ of world's terrestrial carbon. Any change to the boreal forest carbon balance may therefore considerably affect the global atmospheric $\mathrm{CO}_{2}$ (Conard et al., 2002). On average, boreal and temperate vegetation fires represent $4 \%$ of global biomass burning and up to $12 \%$ during extreme burning years, when corresponding $\mathrm{BC}$ emissions account for about $20 \%$ of the worldwide BC emissions from all fires (Lavoue et al., 2000). Thus, boreal forest fires are an important source of air pollutants throughout the Arctic, including BC (Quinn et al., 2008; Lavoue et al., 2000). Due to the light-absorbing properties of $\mathrm{BC}$ and the associated decrease in surface snow albedo, boreal forest fire BC has a signifi- cant radiative impact on the Arctic atmosphere (Quinn et al., 2008; Flanner et al., 2007; Hansen and Nazarenko, 2004).

North American and Eurasian boreal fire regimes differ due to distinctive fuel, weather and fire ecology (Wooster and Zhang, 2004; de Groot et al., 2013). Mean fire intensity and fuel consumption is higher in North America than in Russia, even though the spatial extent of forests is greater in Russia (Wooster and Zhang, 2004; de Groot et al., 2013). Different fire regimes suggest a dominance of crown fires in North America and surface fires in Russia (Wooster and Zhang, 2004; de Groot et al., 2013), thus suggesting the possibility of different chemical pathways in pyro-product production and emissions. Accordingly, Russian fires may burn less fuel than North American fires (de Groot et al., 2013) and thus emit less pyro-products into the atmosphere per unit of area burned (Wooster and Zhang, 2004).

Boreal forest fires in Siberia may have a larger impact on total global fire emissions than those in North America due to the larger Siberian burn area (Stohl, 2006; Stohl et al., 2006). Russian boreal forests, the majority of which are located in Siberia, accounted for 14-20\% of average annual global carbon emissions from forest fires in 1998 (Conard et al., 2002). However, little is known about the emission, transport and deposition of BC from Siberian forest fires to the Arctic. The characterization of Siberian fire plumes is uncertain, due to currently undefined biomass fraction consumed, combustion efficiency, plume injection heights and emission ratios (Paris et al., 2009). Models are sensitive to the conditions and types of fires, such as the injection height of fire emissions (Turquety et al., 2007), and the lack of data about Siberian fires introduces large potential errors in estimating the impact of boreal wildfires on the atmospheric composition (Conard et al., 2002).

Summer atmospheric conditions favour enhanced wet and dry BC deposition in the Arctic, while dry winters allow for longer aerosol lifetimes due to lower wet deposition (Stohl, 2006). Generoso et al. (2007) determined that the 2003 Russian fires contributed to approximately $40-56 \%$ of the total $\mathrm{BC}$ mass deposited north of $75^{\circ} \mathrm{N}$. In fact, model results indicate that boreal forest fire sources, especially Siberian fires, are the dominant summertime source of BC reaching the Arctic, exceeding all contributions from anthropogenic sources (Stohl, 2006). Northern Eurasian and Siberian fire emissions such as BC can reach the Arctic more easily than emissions from North American regions at similar latitudes (Stohl, 2006; Stohl et al., 2006; Lavoue et al., 2000).

\subsection{Biomass burning proxies}

There are many potential indicators or proxies of past fire activity, such as altered products of plant combustion (e.g. charcoal, BC), partially combusted biological material (e.g. fire scars in tree rings), or chemical markers directly produced and volatilized during vegetation combustion (e.g. resin acids, polycyclic aromatic hydrocarbons) (Conedera et 
al., 2009). Some proxies are specific as they are produced solely from biomass burning, such as charcoal in sediment cores, but most others have multiple potential sources other than wildfires (e.g. coal burning or biogenic emissions). Ice cores from polar regions are widely used to reconstruct detailed climate records over the past hundreds of thousands of years, and are thus powerful tools in palaeoclimate research (Legrand and Mayewski, 1997).

Examining forest fires in ice cores started with the pioneering work of Legrand et al. (1992), which suggested that the concentration of ammonium and light carboxylic acids, such as formic and oxalic acids, significantly increase above background levels in Greenland ice layers during forest fire events. This was confirmed by Dibb et al. (1996) and Jaffrezo et al. (1998), who reported a sudden increase of the atmospheric levels of these species at Summit (central Greenland) in August 1994 and June 1993, when biomass burning plumes were transported to the site from the northern Canada. Finally, Kehrwald et al. (2012) showed that the Summit snow layer corresponding to the August 1994 event exhibits oxalate and levoglucosan concentration peaks.

The subsequent work of Legrand and DeAngelis (1996) demonstrates that, on average, high-latitude biomass burning contributes between 20 and $30 \%$ to the formate, oxalate and ammonium deposited in central Greenland over the last 200 years. However, for a typical biomass burning input the authors report strong enhancements with respect to background values for ammonium (up to a factor of 20) and formate (up to a factor of 100), where the ammonium to formate molar ratio during the event is close to unity (Legrand and DeAngelis, 1996). In addition to strong increases of ammonium, formate and oxalate concentrations, Savarino and Legrand (1998) found an increase of nitrate coincident with some of the fire events recorded in Greenland ice, indicating that nitrate is not a good proxy of forest fire inputs to Greenland ice. Finally, potassium is sometimes used to identify the contribution of biomass burning in atmospheric air masses (Andreae, 1983; Gao et al., 2003). Of the available ionic compounds, $\mathrm{K}^{+}$cannot be considered a suitable indicator for forest fire plumes reaching Greenland due to marine and terrestrial sources, even if corrected to remove these contributions (e.g. non-sea-salt and non-crustal $\mathrm{K}^{+}$) (Legrand and DeAngelis, 1996; Savarino and Legrand, 1998).

$\mathrm{NH}_{4}^{+}, \mathrm{NO}_{3}^{-}$and organic acids in Greenland ice were often successfully associated with biomass burning events, where $\mathrm{NO}_{3}^{-}$in particular tends to increase in samples with higher $\mathrm{NH}_{4}^{+}$concentrations (Fuhrer et al., 1996; Whitlow et al., 1994; Savarino and Legrand, 1998). Many high fire years are identifiable by enhanced $\mathrm{NH} 4+$ concentrations in continental environmental archives (Eichler et al., 2011), yet the use of ammonium is less straightforward than in Greenland due to the presence of large biogenic sources in nonpolar regions. However, statistical attempts to recognize forest fire signals from multiple ice core data sets used empiri- cal orthogonal function (EOF) analysis or principal component analysis (PCA), which identify chemical associations between pyro-ion records and differentiate between sources and transport characteristics (Yalcin et al., 2006; Eichler et al., 2011).

The isotopic ratio of atmospheric gases, such as methane $\left(\mathrm{CH}_{4}\right)$ in Antarctic (Ferretti et al., 2005) and Arctic (Sapart et al., 2012) ice cores, has also been used as a fire proxy, but such ratios are also not solely products of biomass burning (Fischer et al., 2008). The isotopic composition of methane $\left(\delta^{13} \mathrm{C}\right.$ of $\left.\mathrm{CH}_{4}\right)$ in ice cores differentiates biogenic from pyrogenic sources (Sapart et al., 2012). Methane is stable in the atmosphere for longer than the atmospheric exchange time and is therefore globally distributed. Hence $\delta^{13} \mathrm{C}$ of $\mathrm{CH}_{4}$ variations are impacted by sources distributed all over the world (Blunier et al., 2007).

$\mathrm{BC}$ is emitted during incomplete combustion of fossil and biofuels in fires ignited by both natural and human sources (Preston and Schmidt, 2006; McConnell et al., 2007). BC is not a single chemical compound, however, and lacks welldefined characteristics (Goldberg, 1985; Masiello, 2004). However, comparison of $\mathrm{BC}$ with vanillic acid, a lignin phenol tracer of conifer combustion (Simoneit, 2002), in an ice core from west central Greenland allowed McConnell (2007) to separate out the contributions of biomass burning and fossil fuels to the BC flux reaching Greenland. Other specific tracers for biomass burning, including levoglucosan (vegetation fires) and $p$-hydroxybenzoic and dehydroabietic acids (conifer fires), have been analysed in high- and mid-latitude ice cores from the Kamchatka Peninsula, northeastern Asia (Kawamura et al., 2012) and from the Tibetan Plateau (Yao et al., 2013).

Monosaccharide anhydrides are one of the few fire proxies that have specific sources (Gambaro et al., 2008; Simoneit, 2002). Levoglucosan (1,6-anhydro- $\beta$-D-glucopyranose) is a monosaccharide anhydride released during biomass burning when cellulose combustion occurs at temperatures $>300^{\circ} \mathrm{C}$ (Gambaro et al., 2008; Simoneit, 2002). As with BC and $\mathrm{NH}_{4}^{+}$, levoglucosan is injected into the atmosphere in convective smoke plumes, deposited on glacier surfaces through wet and dry deposition, and preserved in the snow and ice (Gambaro et al., 2008; Kehrwald et al., 2012; McConnell et al., 2007; Fuhrer and Legrand, 1997). Unlike greenhouse gases, levoglucosan, $\mathrm{NH}_{4}^{+}$and $\mathrm{BC}$ are not homogeneously distributed in the atmosphere as chemical processing causes short lifetimes (of the order of days to weeks) (Hennigan et al., 2010; Fraser and Lakshmanan, 2000; Ramanathan and Carmichael, 2008; Fuhrer and Legrand, 1997) in addition to efficient deposition processes from the atmosphere. Although levoglucosan is oxidized by $\mathrm{OH}$ radicals in the gas phase (Hennigan et al., 2010) and in atmospheric water droplets (Hoffmann et al., 2010), its high concentration in biomass emissions means that levoglucosan remains a strong potential tracer for fire activity even across remote distances 


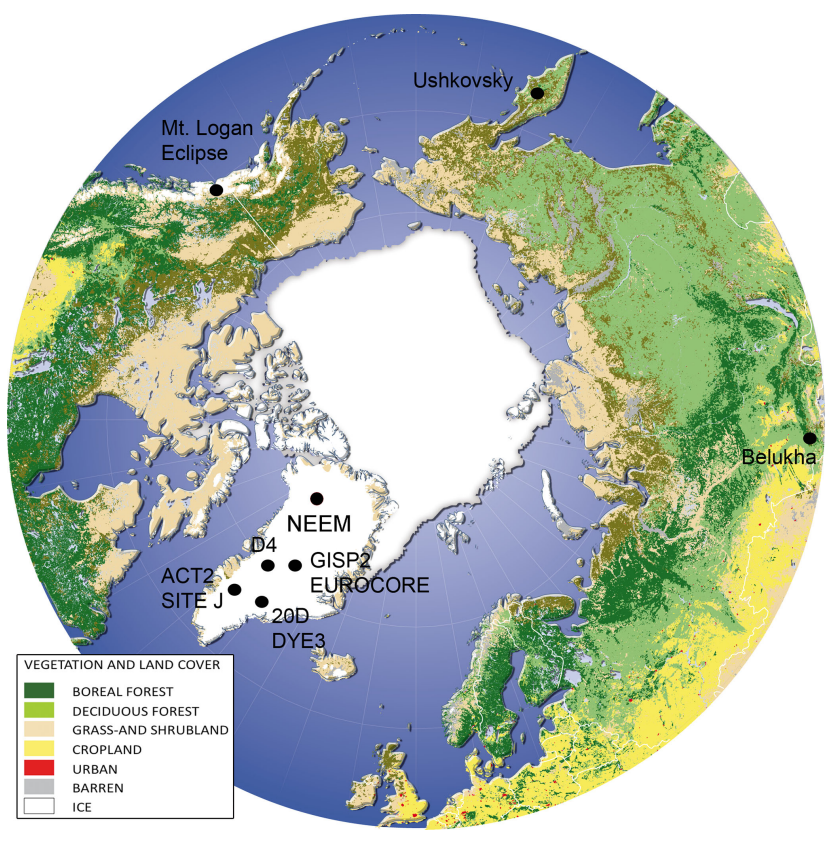

Figure 1. NEEM camp position and representation of boreal vegetation and land cover between 50 and $90^{\circ} \mathrm{N}$. Modified from the European Commission Global Land Cover 2000 database and based on the work of cartographer Hugo Alhenius UNEP/GRIP-Arendal (Alhenius, 2003).

(Fraser and Lakshmanan, 2000; Holmes and Petrucci, 2006, 2007; Kehrwald et al., 2012).

Charcoal deposited both in non-polar ice and sediment cores can also help reconstruct past fire activity. The Global Charcoal Database (GCD) compiles individual charcoal records from terrestrial and marine sediment cores (Supplement Fig. S6) into global or regional reconstructions that provide a benchmark against which other biomass burning records can be compared (Power et al., 2010; Marlon et al., 2008). The charcoal database covers all climatic zones and all major biomes, but data for grasslands and dry shrublands, where low woody biomass limits charcoal production, are limited due to a lack of suitable sampling sites (Marlon et al., 2008). These vegetation types emit large quantities of levoglucosan when burned (Iinuma et al., 2007; Gao et al., 2003), resulting in a possible offset between charcoal and levoglucosan data. Many charcoal sampling sites are located in the US and Europe, and a limited number of GCD sites currently exist in northern Asia (Supplement Fig. S6). As levoglucosan and BC can be transported hundreds to thousands of kilometres (Mochida et al., 2010), they complement GCD reconstructions that record combustion within tens of kilometres of the sampling sites, and provide fire activity data for regions where charcoal records do not exist.

\subsection{Aim of the study}

Here, we use a multi-proxy approach to reconstructing biomass burning in the northern high latitudes during the past 2000 years. Specifically, we report levoglucosan and ammonium concentrations in the upper part of the deep North Greenland Eemian (NEEM) ice core as well as BC measured in the $410 \mathrm{~m}$ NEEM-2011-S1 core (Fig. 1), which was collected adjacent to the deep core in 2011 (Sigl et al., 2013). We compare our results with Northern Hemisphere fire records, climate conditions obtained from historical records and palaeoarchives to identify sources of and controls on fire emissions registered in NEEM. Our approach acknowledges the weaknesses inherent in most fire proxies used in ice core studies and remedies this by integrating the results from multiple fire proxies to identify the robust variations in past biomass burning during the past 2000 years.

\section{Methods}

\subsection{Ice core sampling and analyses}

The international North Greenland Eemian (NEEM) ice core drilling site (Fig. 1) is located in northwest Greenland $\left(77.49^{\circ} \mathrm{N}, 51.2^{\circ} \mathrm{W} ; 2480\right.$ m.a.s.l.; mean annual temperature $-29^{\circ} \mathrm{C}$; accumulation $0.22 \mathrm{~m}$ ice equivalent per year). The deep NEEM ice core (Fig. 1) was drilled from 2008 to 2012 and reached a depth of $2540 \mathrm{~m}$. Ice core analyses were partly performed in the field and partly in the laboratories of the participating nations. Our levoglucosan data set consists of 273 samples from 4.95 to $602.25 \mathrm{~m}$ depth (1999 CE-1036 BCE), where each sample is a $1.10 \mathrm{~m}$ inner core section collected after being melted within the continuous flow analysis (CFA) (Kaufmann et al., 2008) system at the NEEM camp. Samples for levoglucosan determination were transported in a frozen state from the field to Ca' Foscari University of Venice laboratory, where they were stored in a $-20^{\circ} \mathrm{C}$ cold room until analysis. We slightly modified the analytical procedure for determining levoglucosan (see Supplement) using liquid chromatography/negative ion electrospray ionization - tandem mass spectrometry (HPLC/(-)ESI-MS/MS) at picogram per millilitre reported by Gambaro et al. (2008) (Supplement). This analytical method has the advantage of allowing the direct determination of levoglucosan by introducing the melted sample and ${ }^{13} \mathrm{C}_{6}$-labelled internal standard into the HPLC instrument. Preanalytical procedures (analyte extraction and purification) are avoided and sample contamination minimized. $\mathrm{NH}_{4}^{+}$and the other major ions were measured by CFA on the deep NEEM core directly in the field during the 2009 season (Kaufmann et al., 2008). All the major ions are available at millimetre resolution, and we calculated $1.1 \mathrm{~m}$ mean values in order to directly compare with levoglucosan.

The upper $1419 \mathrm{~m}$ of deep NEEM core $\delta^{18} \mathrm{O}$, volcanic fingerprints, electrical conductivity measurement, 
dielectrical profiling, and impurity records can be matched to the NGRIP (North Greenland Ice Core Project) GICC05 extended timescale (Supplement Fig. S7) (Wolff et al., 2010b; Rasmussen et al., 2013). Due to the ice compression and differences in Greenland snow accumulation, each $1.10 \mathrm{~m}$ sample covers 1 to 5-year-long temporal periods. The temporal interval has an associated age error of \pm 1 year from the top of the ice core to the depth of $294.25 \mathrm{~m}(698 \mathrm{CE})$ and from 338.25 to $536.8 \mathrm{~m}$ ( $468 \mathrm{CE}-645 \mathrm{BCE})$. An error of \pm 2 years exists from 295.35 to $336.05 \mathrm{~m}$ depth (692-480 CE) and from 541.20 to $602.25 \mathrm{~m}$ (671-1036 BCE). No official age model is currently available for the upper section $(0.00-19.80 \mathrm{~m})$ of the NEEM ice core. The uppermost $20 \mathrm{~m}$ of the age scale was calculated using a Herron-Langway firn densification model fit to the NEEM-NGRIP tie points for the 20-80 m long firn column (Supplement Fig. S7) (Herron and Langway Jr, 1980).

Continuous flow analysis allows for sub-seasonal reconstructions of BC in the NEEM-2001-S1 core (Sigl et al., 2013) and other Greenland ice cores (McConnell et al., 2007; McConnell and Edwards, 2008; McConnell, 2010). The NEEM-2011-S1 core was collected adjacent to the deep NEEM core (Fig. 1) in summer 2011, and the $410 \mathrm{~m}$ long core was transported to the Desert Research Institute in Reno, NV, USA. The core was cut into $\sim 1.10 \mathrm{~m}$ long samples with cross sections of $\sim 0.033 \mathrm{~m}$ by $0.033 \mathrm{~m}$. These longitudinal samples were analysed in early autumn 2011 using a well-established continuous ice core analytical system (McConnell, 2002; Banta et al., 2008), including determination of $\mathrm{BC}$ concentrations using methods described in McConnell et al. (2007) and McConnell and Edwards (2008). Annual layer counting based on seasonal variations in a number of elements and chemical species, constrained by the known volcanic markers in the deep NEEM and other ice cores, was used to determine the age model with dating uncertainty of $<1$ year. (Sigl et al., 2013). BC was measured using a continuous ice core melter system (McConnell and Edwards, 2008; McConnell et al., 2007) in the $410 \mathrm{~m}$ NEEM-2011-S1 core collected adjacent to the deep NEEM core in 2011 (Fig. 1). We present 1921 BC concentrations from the NEEM-2011S1 cores, spanning the ages 78-1997 CE. A number of seasonally varying elements and chemical species were used to count annual layers in the NEEM-2011-S1 core, resulting in minimal dating uncertainty (Sigl et al., 2013), as for the deep NEEM core dating (Supplement).

The BC and levoglucosan measurements were sampled at different resolutions from two parallel ice cores, where $\mathrm{BC}$ samples and levoglucosan samples represent similar, but not equal, average age of the ice. $\mathrm{BC}$ is also sampled at a higher resolution (sub-annual resolution) than the levoglucosan (one sample continuously covering $1.10 \mathrm{~m}$ of the deep NEEM ice core). In order to avoid temporal resolution loss and the introduction of errors in dating, we chose not to calculate BC averages from the NEEM-2011-S1 core over the same temporal interval covered by the deep NEEM core when seeking to compare pyro-proxies from the two cores, instead leaving them as annual $\mathrm{BC}$ concentrations.

\subsection{Statistics}

One of the first challenges to understanding that levoglucosan reflects variations in fire activity is to assess its relationship with transport variability. Dust and $\mathrm{Ca}^{2+}$ concentrations can be used as crustal particulate tracers in ice cores, and can provide clues as to the relative strength of their source regions, transport variability and transport strength (Fischer et al., 2007; Obrien et al., 1995; Wolff et al., 2010a). The Holocene contribution of sea salts to total Greenland $\mathrm{Ca}^{2+}$ ice concentrations is estimated to be of the order of $10 \%$ (Fischer et al., 2007). In order to avoid including possible errors due to data transformation by using the seawater $\mathrm{Ca}^{2+} / \mathrm{Na}^{+}$ratio, we use $\mathrm{Ca}^{2+}$ as a dust tracer without correcting for sea salt contribution.

\subsection{Short- to long-term fire variation}

For short-term analysis, we consider megafires as levoglucosan peaks with a $\mathrm{Z}$ score $\geq 1\left[\mathrm{Z}\right.$ score $\left.\left.=\left(x_{i}-\bar{x}\right) / \sigma\right)\right]$, corresponding to a concentration $\geq 245 \mathrm{pg} \mathrm{mL}^{-1}$ (Table 1, Supplement Fig. S5). Multi-decadal fire activity was extracted from the levoglucosan and $\mathrm{BC}$ concentration profiles by analysing smoothed data after removing spikes above a fixed threshold (Supplement). We tested different approaches in order to determine multi-decadal fire activity from levoglucosan concentrations. The challenge was to find a suitable statistical tool capable of identifying temporal trends that are not overly affected by the high peaks of anomalous events. The Global Charcoal Database archives hundreds of sedimentary records of fire (Power et al., 2010). Regional and global synthesis allows for the examination of broad-scale patterns in palaeofire activity (Marlon et al., 2013). In order to compare levoglucosan data with decadal to centennial trends in other palaeoclimate records, we first applied the same standardized statistical procedures as were used to analyse the Global Charcoal Database (Marlon et al., 2008; Power et al., 2008). We modified this method for the NEEM data as it is from a single site (unlike the GCD) and correspondence to any outlying values resulting in artifacts into LOWESS (locally weighted scatterplot smoothing). A common approach to isolate the influence of spikes is to fix a threshold and separately study those values. We differ from the GCD procedure in our treatment of individual spikes, as these strongly affect multi-decadal trends, even when using a LOWESS regression model. In summary, to highlight longterm fire changes, we followed the following procedure (details are included in the Supplement):

- removing spikes above a fixed threshold,

- Z-score transformation,

- LOWESS modelling. 
Table 1. Major levoglucosan peaks (with levoglucosan concentrations above the threshold 3rd $Q+1.5$ IR) and their correspondence to other biomass burning proxies. Samples in bold have levoglucosan concentrations above the mean plus one standard deviation. The $\mathrm{NH}_{4}^{+}$samples have the same ages as the levoglucosan samples. Blank spaces demonstrate the absence of high values $(Z$ scores $>1)$; "n.a." means that no values were available.

\begin{tabular}{|c|c|c|c|c|c|c|c|c|c|c|}
\hline \multicolumn{6}{|c|}{ Levoglucosan } & \multicolumn{3}{|c|}{ Black carbon } & \multicolumn{2}{|c|}{ Ammonium } \\
\hline $\begin{array}{r}\mathrm{Sam}_{1} \\
(\mathrm{yr}\end{array}$ & $\begin{array}{l}\text { e age } \\
\text { CE) }\end{array}$ & $\begin{array}{l}\text { Average age } \\
\text { (yr CE) }\end{array}$ & $\begin{array}{l}\text { [levoglucosan] } \\
\left(\mathrm{pg} \mathrm{mL}^{-1}\right)\end{array}$ & $Z$ score $^{1}$ & $Z$ score $^{2}$ & $\begin{array}{l}\text { Age } \\
(\mathrm{yr} \mathrm{CE})\end{array}$ & $\begin{array}{l}{[\mathrm{BC}]} \\
\left(\mathrm{ng} \mathrm{g}^{-1}\right)\end{array}$ & $Z$ score $^{2}$ & $\begin{array}{l}{\left[\mathrm{NH}_{4}^{+}\right]} \\
\left(\mathrm{ng} \mathrm{g}^{-1}\right)\end{array}$ & $Z$ score $^{2}$ \\
\hline 1975 & 1972 & 1973 & 301 & 1.37 & 1.45 & 1972.5 & 6.73 & 1.68 & 13.77 & 1.16 \\
\hline 1791 & 1787 & 1789 & 612 & 3.39 & 3.56 & 1789.5 & 5.81 & 1.26 & & \\
\hline 1706 & 1702 & 1704 & 336 & 1.59 & 1.69 & $\begin{array}{l}1703.5 \\
1702.5\end{array}$ & $\begin{array}{l}10.02 \\
5.85\end{array}$ & $\begin{array}{l}3.15 \\
1.28\end{array}$ & 13.75 & 1.16 \\
\hline 1622 & 1617 & 1620 & 521 & 2.80 & 2.94 & 1619.5 & 6.35 & 1.51 & & \\
\hline $1603^{3}$ & $1593^{3}$ & $1598^{3}$ & $170^{3}$ & $0.51^{3}$ & $0.55^{3}$ & 1594.5 & 5.29 & 1.03 & $14.98^{3}$ & $1.39^{3}$ \\
\hline 1319 & 1313 & 1316 & 193 & 0.66 & 0.71 & & & & & \\
\hline 1177 & 1171 & 1174 & 201 & 0.71 & 0.77 & 1170.5 & 5.80 & 1.26 & & \\
\hline 1112 & 1106 & 1109 & 229 & 0.90 & 0.96 & & & & & \\
\hline 1041 & 1036 & 1039 & 393 & 1.96 & 2.07 & & & & & \\
\hline 979 & 973 & 976 & 245 & 1.00 & 1.06 & 974.5 & 5.38 & 1.07 & & \\
\hline 924 & 919 & 922 & 483 & 2.55 & 2.69 & 922.5 & 18.85 & 7.11 & 21.93 & 2.71 \\
\hline 745 & 739 & 742 & 208 & 0.76 & 0.81 & 739.5 & 12.02 & 4.05 & 13.01 & 1.02 \\
\hline 631 & 625 & 628 & 391 & 1.95 & 2.06 & 630.5 & 11.58 & 3.85 & 26.07 & 3.50 \\
\hline 562 & 556 & 559 & 192 & 0.65 & 0.70 & 559.5 & 9.35 & 2.85 & 15.07 & 1.41 \\
\hline 451 & 446 & 449 & 188 & 0.63 & 0.68 & 446.5 & 8.47 & 2.46 & & \\
\hline 345 & 339 & 342 & 1767 & 10.92 & 11.42 & $\begin{array}{l}345.5 \\
340.5\end{array}$ & $\begin{array}{l}6.26 \\
45.32\end{array}$ & $\begin{array}{l}1.46 \\
18.98\end{array}$ & 15.83 & 1.55 \\
\hline 225 & 219 & 222 & 170 & 0.51 & 0.56 & $\begin{array}{l}224.5 \\
223.5 \\
221.5\end{array}$ & $\begin{array}{l}8.23 \\
7.22 \\
6.69\end{array}$ & $\begin{array}{l}2.35 \\
1.90 \\
1.66\end{array}$ & 16.02 & 1.59 \\
\hline-196 & -202 & -199 & 349 & 1.68 & 1.78 & n.a. & n.a. & n.a. & 26.44 & 3.57 \\
\hline-271 & -277 & -274 & 401 & 2.02 & 2.13 & n.a. & n.a. & n.a. & 22.08 & 2.74 \\
\hline-327 & -333 & -330 & 382 & 1.89 & 2.00 & n.a. & n.a. & n.a. & & \\
\hline-389 & -396 & -392 & 1445 & 8.82 & 9.23 & n.a. & n.a. & n.a. & & \\
\hline-524 & -531 & -527 & 192 & 0.65 & 0.70 & n.a. & n.a. & n.a. & 21.56 & 2.64 \\
\hline $\mathbf{- 5 3 7}$ & -543 & -540 & 266 & 1.14 & 1.21 & n.a. & n.a. & n.a. & 12.97 & 1.01 \\
\hline-584 & -590 & -587 & 185 & 0.61 & 0.66 & n.a. & n.a. & n.a. & & \\
\hline
\end{tabular}

1 Mean and standard deviation calculated for the entire levoglucosan data set (1036 BCE-1999 CE).

${ }^{2}$ Mean and standard deviation calculated for the common period (87-1992 CE) of the BC, levoglucosan and ammonium data set in order to compare data sets covering different temporal periods.

${ }^{3}$ Levoglucosan has been analysed in a four-bag sample (1593-1603 CE); ammonium value is referred to a two-bag sample (1598-1603 CE).

To analyse the cross-correlation between different time series which are irregularly spaced, we used cross-correlation analyses techniques based on Gaussian kernel methods (Bjornstad and Falck, 2001) which are suitable for palaeodata (Rehfeld et al., 2011). To further investigate cross-correlation, we performed a local analysis (local cross-correlation function), where we applied the abovementioned method to temporal windows.

\section{Results}

Pearson and Spearman correlations between $1.1 \mathrm{~m}$ averaged data (Supplement) demonstrate that, of the possible biomass burning-related products measured in the deep NEEM core, levoglucosan concentrations only significantly correlate with ammonium ( $p$ value $<10^{-6}$, with $\alpha=0.05$ ). No correlation is noted between levoglucosan and crustal marker $\mathrm{Ca}^{2+}$ or dust ( $p$ values $>0.45$, with $\alpha=0.05$ ). Analysis of preliminary measurements of other crustal markers (i.e. Ti and $\mathrm{Ba}$ ) in the deep NEEM ice core also shows a lack of correlation with levoglucosan (Gabrieli, J., personal communication, 2014). A similar correlation analysis of BC and other elements and chemical species (data not shown) measured in the NEEM-2011-S1 core indicates that, during preindustrial periods, $\mathrm{BC}$ concentrations generally do not correlate with crustal particulate tracers but do with $\mathrm{NH}_{4}^{+}$and $\mathrm{NO}_{3}^{-}$(J. R. McConnell, personal communication, 2014). Cross-correlation analyses between levoglucosan time series and high-latitude (north of $55^{\circ} \mathrm{N}$ ) Northern Hemisphere charcoal synthesis, NEEM black carbon, Northern Hemisphere land temperature and NEEM pyrogenic methane (Fig. 3) are presented in the Supplement (Figs. S8-S15); 


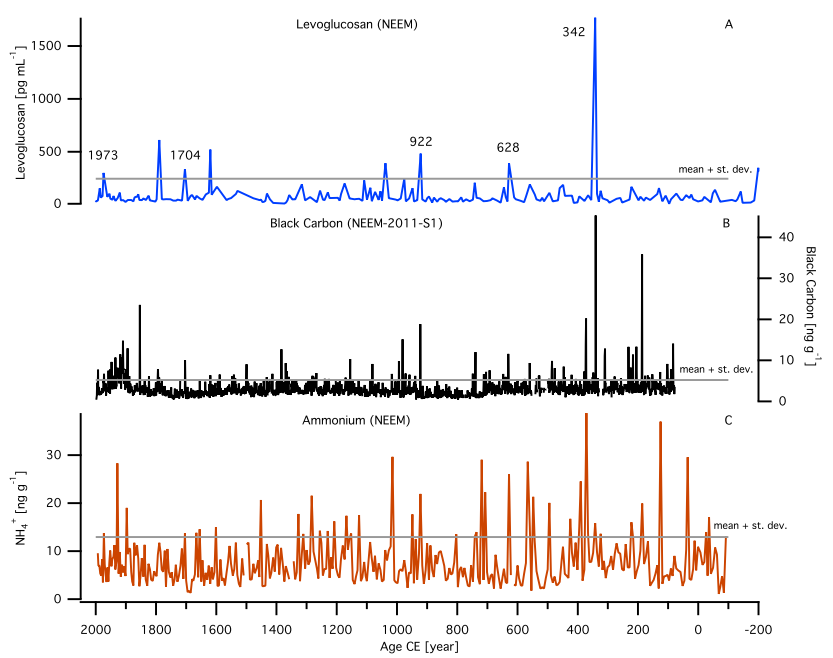

Figure 2. (a) Levoglucosan concentration profile measured in the deep NEEM core including the dates of megafires coincident between levoglucosan, black carbon and ammonium; (b) black carbon concentration profile measured in the NEEM-2011-S1 ice core; (c) ammonium concentration profile in the deep NEEM ice core.

these analyses demonstrate that only the correlation with temperature tends to be significant over regional scales. On local scales, high (positive or negative) correlation is present in almost all measurements, depending on the time period. For example, the period before $500 \mathrm{BP}$ highly positively correlates with temperature and highly negatively correlates with methane.

Atmospheric transport plays a fundamental role in recording fire signatures in polar ice cores. Levoglucosan spikes require that very intense fires occur in the source area and generate levoglucosan-rich plumes that are lifted rapidly. Transport conditions have to be favourable for transport of plumes from the location of fire events to the Arctic. Meteorological conditions regulate loss and dispersion by wet/dry deposition/scavenging of the plumes. If transport and/or meteorological conditions are unfavourable or if precipitation removes the pyro-products before the ice core site, fires will not be detected, or may be detected elsewhere on the Greenland Ice Sheet. In other words, levoglucosan spikes may be produced by mega-events occurring at remote distances or by modest events closer to the NEEM camp. Here we present the megafires recorded at the NEEM position.

Megafires (levoglucosan peaks with Z scores $>1$ ) are observed at 1973, 1789, 1704, 1620, 1039, 976, 922, 628, $342 \mathrm{CE}$ and at 199, 274, 330, 392 and 540 BCE (Fig. 2 and Table 1). Distinct levoglucosan spikes are also synchronous with major peaks in the $\mathrm{BC}$ record (BC Z scores > 3) at 1704, 922, 628 and $342 \mathrm{CE}$ and minor peaks (with BC Z scores $>1)$ at $1973,1789,1620$ and $976 \mathrm{CE}$, respectively. The levoglucosan peak at $342 \mathrm{CE}(\mathrm{Z}$ score $=10.9)$ also occurs in the $\mathrm{BC}$ data, where the $\mathrm{Z}$ score is 19.0 (Table 1).
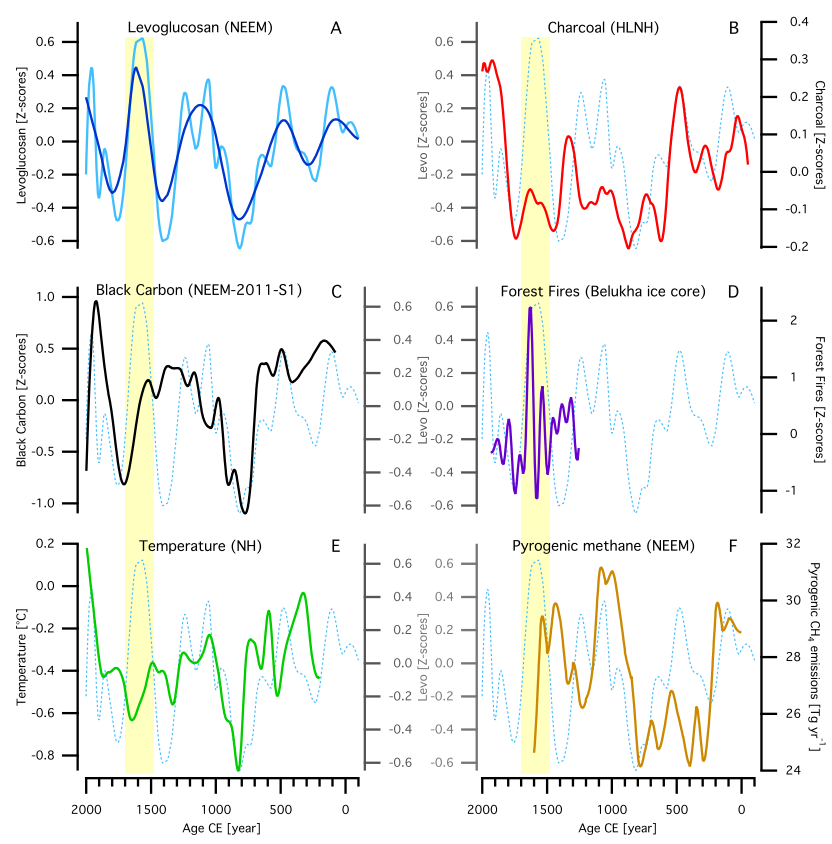

Figure 3. (a) LOWESS with SPAN parameter $(f) 0.1$ (light blue) and 0.2 (dark blue) of levoglucosan $Z$ scores without peaks above the threshold 3rd_Q $+1.5 \times$ IR; (b) high-latitude (above $55^{\circ} \mathrm{N}$ ) Northern Hemisphere (HLNH) Z scores of charcoal influx (200year LOWESS) as reported in Marlon et al. (2008) (red) and smoothed levoglucosan with $f=0.1$ as in (a) (dashed line); (c) LOWESS with $f=0.1$ of black carbon $Z$ scores without peaks above the threshold 3rd_Q+ $1.5 \times$ IR (black) and smoothed levoglucosan (dashed line); (d) Siberian forest fire reconstruction (Eichler et al., 2011) (purple) and smoothed levoglucosan (dashed line); (e) LOWESS with $f=0.1$ of Northern Hemisphere land temperature (Mann et al., 2008) and smoothed levoglucosan (dashed line); (f) pyrogenic $\mathrm{CH}_{4}$ emissions inferred from the deep NEEM core (Sapart et al., 2012) (light brown) and smoothed levoglucosan (dashed line). The yellow vertical bar indicates the period of strongest fire activity.

Strong fluctuations in the temporal profile dominate the record from decadal to centennial perspectives. Relative maxima in the levoglucosan profile are evident between 1000 and $1300 \mathrm{CE}$ and 1500 and $1700 \mathrm{CE}$, and with a lesser extent around $500 \mathrm{CE}$ and $100 \mathrm{CE}$, while the lowest fire activity is evident around 700-900 CE, and with a lesser extent around 1300-1500 and 1700-1800 CE (Fig. 3a). Smoothed $\mathrm{BC}$ concentration is high from 100 to $700 \mathrm{CE}$, and after an abrupt decrease it offers the lowest values between 700 and $900 \mathrm{CE}$. Between 1000 and $1600 \mathrm{CE}$ and 1600 and $1800 \mathrm{CE}$ the $\mathrm{BC}$ profile shows a relative maximum and minimum, respectively, while the absolute maximum in $\mathrm{BC}$ concentration peaks around $1900 \mathrm{CE}$. 


\section{Discussion and interpretation}

\subsection{Biomass burning tracers in the NEEM ice core}

\subsubsection{Major ions transport and deposition on the Greenland Ice Sheet}

Dust, major ions and levoglucosan may not have the same source regions and/or transport history, but comparing these proxies may provide insight into common or differing air masses affecting the NEEM site. Increased wind speeds result in greater dust concentrations and larger particles in ice cores (Ruth et al., 2003; Fischer et al., 2007). The lack of correlation between crustal markers and levoglucosan suggests that levoglucosan enhancements are not only caused by increased wind strength or transport efficiency, but also reflect changes in source activity (forest fires). This evidence differs from the conclusion of Kawamura et al. (2012), who speculated that enhanced atmospheric transport rather than an increase in fire activity may affect levoglucosan concentrations.

Ammonium has multiple anthropogenic and natural sources, mainly emissions from soil and vegetation, and thus background ammonium values in polar ice are strongly linked to biogenic emissions and temperature changes (Fuhrer et al., 1993; Fuhrer et al., 1996; Legrand et al., 1992; Fuhrer and Legrand, 1997). Basing NEEM fire reconstructions only on ammonium concentrations that are not corrected for the natural variability could potentially overestimate major fire events; however, comparing various fire proxies from the same core supplements biomass burning interpretations. The literature uses PCA for pyroreconstructions (Yalcin et al., 2006; Eichler et al., 2011). Incorporating as many fire proxies as possible within the same ice core allows for a more robust reconstruction of past burning, but eigenvectors incorporate other chemical species that, even if they are fire-related compounds, are not fire tracers $\left(\mathrm{NO}_{3}^{-}, \mathrm{H}_{2} \mathrm{O}_{2}\right)$. We therefore compare individual fire tracers in NEEM rather than using PCA as a biomass burning reconstruction.

\subsubsection{Extreme fire events}

Levoglucosan data exhibit high variability (Fig. 2) due to the absence of background atmospheric levoglucosan values. Levoglucosan is only injected into the atmosphere during biomass burning events; no continuous emission processes exist. Individual levoglucosan spikes are therefore likely generated either by short "megafires", by localized fire events or by efficient transport of distant fires rather than by longterm increases in fire activity (Fig. 2 and S5 in the Supplement). In addition, the magnitude of spikes has to be high enough to not be lost/smoothed when analysing multi-year $1.1 \mathrm{~m}$ ice samples. As the mean accumulation rate in north central Greenland has been relatively constant over the past
3000 years (Andersen et al., 2006), we present levoglucosan and $\mathrm{BC}$ concentrations rather than fluxes.

Many levoglucosan spikes correspond to documented fire activity in Greenland or in other Northern Hemisphere ice cores, and are generally supported by the other pyro-proxies measured in the NEEM ice core (Table 1). The majority of fire events inferred from the NEEM ice core were simultaneously recorded by levoglucosan and $\mathrm{BC}$. $\mathrm{NH}_{4}^{+}$spikes replicate many of the levoglucosan spikes ( 8 of the 14 levoglucosan spikes with Z score $>1$ ). Only the 1039 CE levoglucosan peak is not duplicated by any of the other proxies (Table 1). The peak at $342 \mathrm{CE}$ contains by far the highest concentrations of both levoglucosan and $\mathrm{BC}$ present in our data sets, and corresponds to the largest fire event in the past 2000 years recorded by several charcoal records in the northern US and Canadian Rockies (Brunelle et al., 2005; Hallett et al., 2003).

We cannot exclude the possibility that local phenomena in Greenland, rather than extensive events, may be responsible for some of the large levoglucosan spikes. Several levoglucosan spikes were recorded in a relatively brief period between $\sim 920$ and $1110 \mathrm{CE}$. This period coincides with the foundation of Viking settlements in Greenland beginning in $982 \mathrm{CE}$ in southwest Greenland, relatively close to the NEEM site. Historical records show that Greenland Viking settlements burned vast quantities of wood for extracting iron from bogs for tool production, and these local, not necessarily extensive, fires may account for the levoglucosan peaks during this time period (Diamond, 2005). Future trace metal analyses of the NEEM ice core can help demonstrate whether relatively local metal production may have caused these levoglucosan peaks.

Other ice core records provide comparisons of fire events that allow for an examination of the spatial extent of past short-lived fire activity. A prominent 1617-1622 CE levoglucosan peak coincides with high fire activity inferred from oxalic acid analyses recorded in the Greenland Site $\mathrm{J}$ ice core (Kawamura et al., 2001), even if this event is not recorded in ice core from other locations in Greenland (e.g. Savarino and Legrand, 1998). Contemporaneous fire signatures to 17871791 CE peak are reported in Greenland (GISP2, 20D) and Canadian ice cores (Eclipse Icefield and Mt. Logan) (Yalcin et al., 2006; Whitlow et al., 1994). The strongest fire activity recorded in the Ushkovsky (Kamchatka) ice core occurs in 1705, 1759, 1883, 1915, 1949 and 1972 CE (Kawamura et al., 2012). Mega-events are present as both levoglucosan and BC peaks in NEEM in 1704 and 1973 CE and as a BC peak in 1914.5 and 1947.5 CE (Fig. 2).

Due to multiple anthropogenic BC sources after the Industrial Revolution, we cannot directly compare $\mathrm{BC}$ and levoglucosan after $1850 \mathrm{CE}$, but we can compare $\mathrm{BC}$ between NEEM and other Arctic sites and use our data to discriminate fire, volcanic or anthropogenic emissions. The maximum BC concentration $\left(16 \mathrm{ng} \mathrm{g}^{-1}\right)$ in the entire Greenland D4 ice core occurred in $1908 \mathrm{CE}$ (McConnell et al., 
2007). The second-highest $\mathrm{BC}$ peak $\left(15 \mathrm{ng} \mathrm{g}^{-1}\right)$ over the past millennium in the NEEM-2011-S1 is dated to 1909.5 CE (Fig. 2b). This timing is relatively coincident with the Tunguska event, a bolide impact in western Siberia occurring in June 1908. An ammonium spike in 1910 CE in the GISP2 ice core (Taylor et al., 1996) was attributed to large conflagrations in the northern United States and southern Canada. The highest ammonium peak in a Summit, Greenland, ice core spanning 1908-1989 CE occurred in 1908 CE and is synchronous with increases in formate, oxalate, glycolate and BC within the same core (Legrand et al., 1995). Legrand et al. (1995) ascribe this event to North American forest fires rather than the Tunguska event. This conclusion is supported by a vanillic acid peak, a source-specific tracer for conifers (Simoneit, 2002), in the D4 (central Greenland) ice core during this same time period (McConnell et al., 2007) and by a synchronous, extremely limited growth of regional trees (drought proxy) in northwestern Ontario (St. George et al., 2009). Levoglucosan and ammonium spikes in the NEEM (northwestern Greenland) ice core do not record this strong fire event. This evidence suggests that $\mathrm{BC}, \mathrm{NH}_{4}^{+}$and $\mathrm{NO}_{3}^{-}$ peaks in ice cores may not be caused by forest fires during 1908 CE. Ammonium may have been produced by a Haberlike process (Melott et al., 2010) where high pressure and temperature conditions generated by the Tunguska comet entering the atmosphere created reactions in the atmospheric nitrogen and hydrogen from the comet ice, thereby accounting for both the ammonium and nitrate enhancements in some Greenland ice cores (Melott et al., 2010). In addition, comparisons of $\mathrm{BC}$ and toxic heavy metals in the ACT 2 core from southern Greenland (McConnell and Edwards, 2008), as well as BC and non-sea-salt sulfur in the D4 ice core from central Greenland (McConnell et al., 2007), indicate that $>80 \%$ of the $\mathrm{BC}$ during this period is associated with industrial emissions (primarily coal burning). All three pyro-markers record a strong fire signature in the NEEM ice core in 1973 AD. This fire event is synchronous (within the age model error) and probably related to an anomalous heat wave and severe droughts in 1972 CE in Russia (Dronin and Bellinger, 2005; Golubev and Dronin, 2004; The Palm Beach Post, 9 August 1972; The New York Times, 9 August 1972, New York; Battisti and Naylor, 2009).

\subsubsection{Decadal to centennial fire activity variability}

The D4 site demonstrates a gradual rise in $\mathrm{BC}$ concentrations after $1850 \mathrm{CE}$ and a rapid increase after $1888 \mathrm{CE}$, before beginning a gradual decline through the late 1940s followed by a clear drop in 1952 CE (McConnell et al., 2007). This trend is generally confirmed by BC in the NEEM-2011-S1 ice core, where $\mathrm{BC}$ shows a peak that slowly increases from $\sim 1750 \mathrm{CE}$, followed by a sharp enhancement during the late 1800s (Fig. 3c).

Biomass burning was the major source of $\mathrm{BC}$ to central Greenland before $1850 \mathrm{CE}$, as revealed by the close corre- lation between $\mathrm{BC}$ and vanillic acid, an organic combustion marker released by coniferous trees (McConnell et al., 2007). After $1850 \mathrm{CE}$, the influence of industrial emissions, particularly coal, as a source of $\mathrm{BC}$ is clear through comparisons to non-sea-salt sulfur (McConnell et al., 2007) and industrial heavy metals such as lead, thallium and cadmium in the southern Greenland ACT2 core (McConnell and Edwards, 2008). The NEEM-2011-S1 BC record contains its highest concentrations from $1850 \mathrm{CE}$ to the present, reflecting the input of these new sources.

The levoglucosan profile contains moderately high mean values during the 1900s, but other centennial-scale peaks, such as those that centred around $\sim 1600 \mathrm{CE}$, have higher concentrations (Fig. 2a). Reasons for the general divergence of $\mathrm{BC}$ and levoglucosan profiles may be due to the fact that black carbon has an average atmospheric lifetime of a few days to 1 week (Ramanathan and Carmichael, 2008; Bauer et al., 2013; McConnell et al., 2007). The diverse range of BC emission sources and the different atmospheric lifetime of levoglucosan may result in BC representing a separate emission source area to the levoglucosan record. Levoglucosan yield is variable and strongly depends on combustion temperature, biomass composition and flame conditions (Gao et al., 2003; Oros and Simoneit, 2001a, b; Weimer et al., 2008). Thus, levoglucosan cannot be used to characterize and quantify BC in environmental samples (Kuo et al., 2008). In addition, different temporal resolution for $\mathrm{BC}$ and levoglucosan records may result in differences after removing spikes and applying LOWESS. Levoglucosan can only be produced by cellulose pyrolysis; thus the different pattern between the records post- $1850 \mathrm{CE}$ mainly reflects the differences between biomass burning and industrial activity.

The NEEM levoglucosan centennial-scale maximum (1500-1700 CE, Fig. 3a), the highest of the past two millennia, coincides with data from the Belukha ice core, Siberia (Eichler et al., 2011), that documents a period of increased fire activity between 1550 and 1700 CE, within which 1600 $1680 \mathrm{CE}$ recorded the highest forest fire activity from the last 750 years (Fig. 3d). High fire activity between 1500 and $1600 \mathrm{CE}$ was also inferred from formate and ammonium analyses on the Eurocore Greenland ice core, when "high frequency and low intensity of fires" were synchronous with dry climate conditions (Savarino and Legrand, 1998).

The high-latitude Northern Hemisphere (HLNH) $>55^{\circ}$ NGCD composite curve registers a global longterm decline in fire activity from 0 to $1750 \mathrm{CE}$ (Marlon et al., 2008). A decreasing amount of ammonium originating from biomass burning is also deposited in the GRIP ice core (Fuhrer et al., 1996), but this trend is not clearly supported by levoglucosan data during the past two millennia (Fig. 3b). The prominent levoglucosan minimum between 700 and $900 \mathrm{CE}$ coincides with a minimum in the BC profile and HLNH $>55^{\circ} \mathrm{NGCD}$ (Fig. 3). The HLNH $>55^{\circ} \mathrm{N} \mathrm{GCD}$ and levoglucosan data differ near $1600 \mathrm{CE}$ when the HLNH $>55^{\circ} \mathrm{N} \mathrm{GCD}$ demonstrates a modest increase in fire activity, 
while the smoothed NEEM levoglucosan strongly peaks (Fig. 3b). This period of decadal-scale increased biomass burning is seen in both the levoglucosan and $\mathrm{BC}$ records in the NEEM ice cores, including individual levoglucosan peaks with $\mathrm{Z}$ scores up to 2.8 (Table 1). We infer that the $1500-1700$ CE maximum in fire activity is due to increased Eurasian boreal forest fires (Fig. 3), which are probably under-represented in the GCD, reflecting the bias in the geographical distribution of GCD sites. Over 50 high-latitude North American sites exist, yet Siberia only has less than 10 lake cores $>60^{\circ} \mathrm{N}$ which span a distance of over $7000 \mathrm{~km}$.

Sapart et al. (2012) argue that changes in the $\delta^{13} \mathrm{C}$ of $\mathrm{CH}_{4}$ record cannot be explained without biomass burning variability. Methane isotopic variations during the past two millennia (Fig. 3f) correlate with anthropogenic activities, which have contributed to the methane budget before industrial times (Sapart et al., 2012). Methane emissions may be linked to early industrial activity, including copper and lead smelting, but levoglucosan is not released during coal combustion needed for early industrial activities. High $\delta^{13} \mathrm{C}$ values between 800 and $1200 \mathrm{CE}$, and to a lesser extent from 100 until $200 \mathrm{CE}$, corresponds to increased levoglucosan and $\mathrm{BC}$ concentrations. The pronounced levoglucosan peak centred on $\sim 1600$ CE only partially overlaps with the pyrogenic methane record, where $\delta^{13} \mathrm{C}$ peaks in the 1400 s to 1500 s. Despite these differences, the NEEM $\delta^{13} \mathrm{C}$ of $\mathrm{CH}_{4}$ isotopic record contains some similar features to the levoglucosan data (Fig. 3f), even though the two proxies have different sources and geographical distributions.

\subsection{Source of NEEM fire products}

\subsubsection{Fuel loads and circulation patterns}

Stable oxygen isotope $\left(\delta^{18} \mathrm{O}\right)$ data demonstrate that the circulation pattern of air masses reaching the Greenland Ice Sheet did not significantly change over the last 10000 years (Vinther et al., 2006). We therefore assume that the atmospheric transport of biomass burning plumes should not have significantly changed during the past two millennia. The isotopic composition of dust in ice cores helps determine the geographic origin of particulate matter reaching Greenland. Holocene mineral dust in the NGRIP (North Greenland Ice core Project) ice core has an Asian origin, with the Gobi and Taklimakan deserts as the best source candidates. (Bory et al., 2003; Bory et al., 2002; Lupker et al., 2010). The above studies argue that North America and North Africa are not potential dust sources, as both regions have higher $\mathrm{K} / \mathrm{C}$ ratios and higher smectite contents than dust extracted from NGRIP. Although mineral dust and biomass burning products are subject to different transportation styles and atmospheric interactions, these dust studies demonstrate the influence of Asian sources on material transported to the Greenland Ice Sheet.
Earth's boreal forests cover 9-12 million km² (Fig. 1), extending across Scandinavia, Russia and North America, representing approximately $10 \%$ of Earth's land cover and onethird of the total global forested area (Zhang et al., 2003; Canadian Forest Canadian Forest Service, 2005). Boreal forest forms a green belt just below the Arctic Circle (55 to $70^{\circ} \mathrm{N}$ ), interrupted only by the Pacific and Atlantic oceans, and thus forms the major fuel source for fire emissions reaching the Greenland Ice Sheet. We consider both coniferous and deciduous forests at $\geq 55^{\circ} \mathrm{N}$ as boreal forests (Fig. 1). Russian forests alone represent $\sim 25 \%$ of global terrestrial biomass (Zhang et al., 2003). Two-thirds of boreal forests are located within the 17 million $\mathrm{km}^{2}$ of the Russian Federation (Zhang et al., 2003).

Arctic snow samples across the Greenland Ice Sheet and associated back trajectories from a single year highlight the importance of Russian boreal forests as a biomass burning source, and suggest that $55 \%$ of modern $\mathrm{BC}$ reaching the Greenland Ice Sheet originates from Russian biomass burning, while $40 \%$ is from North America, and only 5\% is from anthropogenic emissions (Hegg et al., 2009). A 44-year record of 10-day isobaric back trajectories reaching Summit, Greenland (Kahl et al., 1997), indicates that more summer (fire season) trajectories originate over North America (46\% at $500 \mathrm{hPa}$ and $85 \%$ at $700 \mathrm{hPa}$ ) than from eastern Asia $(20 \%$ at $500 \mathrm{hPa}$ and $6 \%$ at $700 \mathrm{hPa}$ ) or from Europe and western Asia (only $6 \%$ at $500 \mathrm{hPa}$ ). The pressure of $500 \mathrm{hPa}$ corresponds to $\sim 5-6 \mathrm{~km}$ a.s.l and is typical of mid-tropospheric circulation, while $700 \mathrm{hPa}$ is closer to the altitude of the Summit camp. A model intercomparison demonstrates that North America and Europe each contribute $40 \%$ of the total anthropogenic BC deposited on Greenland (Shindell et al., 2008). These models only investigate anthropogenic sources and explicitly state that biogenic Siberian emissions are not included in their estimates. McConnell et al. (2007) demonstrate that variations in $\mathrm{BC}$ matched changes in the specific coniferous fire marker vanillic acid measured in the Greenland D4 ice core before 1850 CE yet do not correlate over the industrial period of 1850-1950 CE. This lack of correlation may result from the majority of $\mathrm{BC}$ arriving to Greenland between 1850 and 1950 CE having a North American anthropogenic source, and from $1951 \mathrm{CE}$ to the present having an Asian industrial source, separate from any fire activity (McConnell et al., 2007). Therefore, any analysis of Greenland $\mathrm{BC}$ from $1850 \mathrm{CE}$ onward should not be considered a purely biomass burning indicator, and the sources for $\mathrm{BC}$ and fire emissions may substantially differ.

\subsubsection{Levoglucosan sources}

Back-trajectory and model analyses suggest that North American and Siberian forests are the dominant sources of biomass burning aerosols, for which North America is likely the most important contributor due to the proximity to the NEEM location. Asia has generally been ignored as 
a biomass burning aerosol source for Greenland, due in part to the days required for air mass travel time. However, the back-trajectory analyses do demonstrate that Asia, although it is a lesser source, is a possible aerosol source.

The Ushkovsky (Kawamura et al., 2012) and Belukha (Eichler et al., 2011) ice cores both contain up to multidecadal periods of increased fire activity that are similar to peaks in the NEEM ice core. Correspondences between regional droughts and increased fire activity are present in multiple northern and central Asian proxies (Table 2). Extreme droughts in northern central Asia (Thompson et al., 2000; Shen et al., 2007) correspond in timing with NEEM levoglucosan spikes (Table 2), therefore supporting that Asia may be an important fire source of burning signatures inferred in Arctic ice fields during strong fire events caused during severe dry years.

Boreal wildfires can generate sufficient sensible heat during the combustion process to initiate deep convection and inject particles into the upper troposphere and lower stratosphere, resulting in longer atmospheric lifetimes and more efficient transport of biomass burning aerosols (Damoah et al., 2004; Trentmann et al., 2006; Dentener et al., 2006; Hodzic et al., 2007). Regional droughts result in large amounts of available deadwood as fuel, resulting in intense fires capable of generating deep convection (van Mantgem et al., 2009; Westerling et al., 2006; Trentmann et al., 2006; Hodzic et al., 2007).

\subsection{Climatic and anthropogenic influences on decadal to centennial changes in fire activity}

\subsubsection{Temperature and droughts}

Temperature anomalies during the past 2000 years are not globally synchronous. The regional pattern of the Medieval Warm Period (MWP) results in differing times of maximum warming by region. Global temperature anomalies were highest between 950 and 1250 CE (Mann et al., 2009), whereas Northern Hemisphere (and especially Russian) temperatures were elevated between 1000 and $1300 \mathrm{CE}$ (Crowley and Lowery, 2000; Hiller et al., 2001) or 1000 and $1100 \mathrm{CE}$ (Moberg et al., 2005). Such temperature anomalies correlate with increased fire activity in palaeofire reconstructions inferred from various environmental archives, including the Eclipse Icefield in the Yukon, Canada (1240-1410 CE) (Yalcin et al., 2006); Eurocore (1200-1350 CE) (Savarino and Legrand, 1998) and GISP2 ice cores (1200-1600 CE) (Taylor et al., 1996); and in the HLNH $>55^{\circ}$ N GCD between 1000 and 1400 CE (Marlon et al., 2008). The Little Ice Age (LIA) is characterized by relatively cold conditions between 1580 and $1880 \mathrm{CE}$ (Pages 2k, 2013) but varies regionally between 1400 and 1700 CE (Mann et al., 2009), 15801720 CE (Christiansen and Ljungqvist, 2012) and 13501850 CE (Wanner et al., 2008). Low fire activity is observed in Eurocore (Summit, Greenland) (Savarino and Legrand,
1998) from 1600 to $850 \mathrm{CE}$ and in the global $\mathrm{NH}$ curve (based on GCD syntheses) centred around 1750 CE (Marlon et al., 2008). The levoglucosan profile suggests a correspondence between fire activity observed in the deep NEEM ice core and HLNH terrestrial temperature anomaly (Mann et al., 2008) during the 700-900 CE and 1700-1800 CE cooling, and during the 1000-1300 CE warming. Fire activity inferred from the deep NEEM ice core is consistent with the MWP and LIA climatic conditions, except for the strong difference between temperature and fire activity noted throughout the levoglucosan maximum centred around 1600 CE (Fig. 3e).

Ice core and tree-ring proxy records and archival evidences document extensive north-central Asian droughts concurrent with the strongest centennial-scale levoglucosan concentrations during the 16th and 17th centuries, including two strong punctual events (1593-1603 CE and 1617-1622 CE) (Fig. 2, Table 1 and 2). The Siberian Belukha ice core identifies a period of exceptionally high forest-fire activity between 1600 and $1680 \mathrm{CE}$, following a drought period during 1540$1600 \mathrm{CE}$, which is coincident with the decadal to centennial highest NEEM levoglucosan concentrations (Eichler et al., 2011). This period coincides with the Late Ming Weak Monsoon Period (1580-1640 CE) (Zhang et al., 2008), which has been suggested to have contribuited as contributing to the decline of the Ming Dynasty. Two central and northern Asian droughts (1586-1589 CE and 1638-1641 CE) were the most extreme of the past five centuries (Shen et al., 2007), yet occurred during relatively cold periods ( $\mathrm{Li}$ et al., 2009; Cook et al., 2010; Yang et al., 2002; Tan et al., 2003) and covered much of central Asia (Fang et al., 2010). The 1586-1589 CE drought resulted in the desiccation of Lake Taihu (the third largest freshwater lake in China), and the even more spatially extensive 1638-1641 CE drought event resulted in no outflow of the Yellow River (Shen et al., 2007). Levoglucosan and BC concentrations from the NEEM ice core contain outlying peaks in 1702-1706 CE and 1787-1791 CE, during a period of low centennial-scale fire activity. A network of tree-ring chronologies and historical documents (Grove, 1998; Cook et al., 2010) report extensive drought conditions in China and Mongolia throughout these periods (Table 2), while the Dasuopu ice core (Thompson et al., 2000) demonstrates that the 1790-1796 CE drought was the most intense arid period of the last millennium. A high-resolution determination of continental dust in the Dye-3 Greenland ice core $\mathrm{Sr}, \mathrm{Nd}$ and $\mathrm{Hf}$ isotopic composition from 1786 to $1793 \mathrm{CE}$ established that the majority of the samples have an Asian origin (Lupker et al., 2010). The highest levoglucosan peaks correspond to epic Asian droughts, as summarized in Table 2 - these droughts being among the most severe in the last millennium.

However, North American droughts may have also affected fire activity archived in the NEEM ice cores. Elevated aridity and megadroughts during the MWP (900-1300 CE), coincident with levoglucosan peaks, affected large areas of North America and were more prolonged than any 20th 
Table 2. Asian droughts recorded in various proxies with strong fire events (a) and with centennial fire activity in the 16th and 17th century inferred from levoglucosan analysis (b).

\begin{tabular}{|c|c|c|c|c|}
\hline Age & Location & Proxy & Reference & Comment \\
\hline 1171-1177 & NEEM ice core & levoglucosan & this work & strong event $^{1}$ \\
\hline 1170 & $\begin{array}{l}\text { Taihu drainage basin } \\
\text { China, eastern coast }\end{array}$ & historical climatic records & Wang et al. (2001) & abrupt dry/wet climate change \\
\hline 1313-1319 & NEEM ice core & levoglucosan & this work & strong event ${ }^{1}$ \\
\hline $1320-1370$ & $\begin{array}{l}\text { Northern China } \\
\text { (reconstruction based on different palaeo- } \\
\text { climate archives) }\end{array}$ & flood/drought index & $\begin{array}{l}\text { Yang et al. (2007) and refs. } \\
\text { therein }\end{array}$ & high dust fall frequency \\
\hline $1330 \mathrm{~s}$ & $\begin{array}{l}\text { Dasuopu ice core, Himalaya } \\
\text { (India and Asia as source regions) }\end{array}$ & $\delta^{18} \mathrm{O}$, dust, $\mathrm{Cl}^{-}$ & Thompson et al. (2000) & monsoon failure \\
\hline $1593-1603$ & NEEM ice core & levoglucosan & this work & strong event ${ }^{1}$ \\
\hline $1617-1622$ & NEEM ice core & levoglucosan & this work & mega-event $^{2}$ \\
\hline $\begin{array}{l}1578-1582 \\
1600-1644\end{array}$ & Mongolia & tree ring & Davi et al. (2010) & $\begin{array}{l}\text { 2nd and } 1 \text { st in order of severity since } \\
1520\end{array}$ \\
\hline 1590s-1600s & Central High Asia & tree ring & Fang et al. (2010) & \\
\hline $1618-1635$ & $\begin{array}{l}\text { Taihu drainage basin } \\
\text { China, eastern coast }\end{array}$ & historical climatic records & Wang et al. (2001) & abrupt change to dry period \\
\hline 1702-1706 & NEEM ice core & levoglucosan & this work & mega-event $^{2}$ \\
\hline 1694-1705 & $\begin{array}{l}\text { Changling Mountains, } \\
\text { North-central China }\end{array}$ & tree ring & Feng et al (2011) & $\begin{array}{l}\text { coincident with Maunder } \\
\text { Minimum }^{3}\end{array}$ \\
\hline 1787-1791 & NEEM ice core & levoglucosan & this work & mega-event $^{2}$ \\
\hline $1795-1823$ & $\begin{array}{l}\text { Changling Mountains, } \\
\text { north-central China }\end{array}$ & tree ring & Chen et al. (2012) & coincides with Dalton Minimum ${ }^{3}$ \\
\hline 1790-1799 & $\begin{array}{l}\text { North Helan Mountain, } \\
\text { Inner Mongolia }\end{array}$ & tree ring & Liu et al. (2004) & \\
\hline $1610-1710$ & $\begin{array}{l}\text { Northern China } \\
\text { (reconstruction based on different palaeo- } \\
\text { climate archives) }\end{array}$ & flood/drought index & $\begin{array}{l}\text { Yang et al. (2007) and refs. } \\
\text { therein }\end{array}$ & high dust fall frequency \\
\hline $1540-1600$ & $\begin{array}{l}\text { Siberian Altai } \\
\text { (southern Siberia) }\end{array}$ & ice core pollen data and dust & Eichler et al. (2011) & $\begin{array}{l}\text { extremely dry period followed by high } \\
\text { fire activity }\end{array}$ \\
\hline $1414-1560$ & $\begin{array}{l}\text { Lake Teletskoye, Republic of Altai (Rus- } \\
\text { sian Federation) }\end{array}$ & sediment core pollen data & Andreev et al. (2007) & \\
\hline $1450-1600$ & Eastern China & historical documents & Chu et al. (2008) & negative snow anomaly events \\
\hline $1400-1550$ & $\begin{array}{l}\text { East Juyanhai Lake } \\
\text { Inner Mongolia }\end{array}$ & $\begin{array}{l}\text { sedimentology and geochemical } \\
\text { parameters }\end{array}$ & Chen et al. (2010) & extremely arid conditions \\
\hline $1630 s-1640 s$ & Xiaolong Mountain, central China & tree ring & Fang et al. (2012) & $\begin{array}{l}\text { one of most severe droughts of the past } \\
400 \text { years }\end{array}$ \\
\hline 1630s-1640s & China and Mongolia & tree ring & Li et al. (2009) & \\
\hline $1640 \mathrm{~s}$ & $\begin{array}{l}\text { Dasuopu ice core, Himalaya } \\
\text { (India and Asia as source regions) }\end{array}$ & $\delta^{18} \mathrm{O}$, dust, $\mathrm{Cl}^{-}$ & Thompson et al. (2000) & monsoon failure \\
\hline $1640 s-1650 s$ & Central High Asia & tree ring & Fang et al. (2010) & most severe megadrought \\
\hline
\end{tabular}

1 This event represents levoglucosan concentration above the threshold 3 rd $Q+1.5 \mathrm{IR}$, where $3 \mathrm{rd} Q$ is the third quartile and IR is the interquartile range, calculated as the difference

between the third quartile and the first quartile. This peak was removed from the long-trend analysis.

2 This event represents levoglucosan concentration above the mean plus one standard deviation.

3 As noted by Chen (2012), the drying of the late 1600s to early 1700s, and the drying of the late 1700s to early 1800 s, seen in the precipitation reconstructions, coincides with periods of low solar irradiance, the Dalton Minimum and the Maunder Minimum, respectively.

${ }^{4}$ Generally drought is recorded in tree rings as a sustained narrowness of growth rings. 
century droughts (Cook et al., 2004; Stahle et al., 2000). Dry conditions during the 16th century were also inferred in the Canadian Prairie provinces (St. George et al., 2009) and in western North America (Stahle et al., 2000). Tree rings from Canada record low growth in 1595 CE and 1790s (St. George et al., 2009). A strong fire event is recorded in levoglucosan and ammonium in a $2.20 \mathrm{~m}$ NEEM sample dated 1593-1603 CE, and by a BC spike in the NEEM-2011-S1 in 1594.5 CE. Levoglucosan and BC also peak $~ 1789$. 1790s was the driest decade in southwestern Canada (Sauchyn and Skinner, 2001; Sauchyn and Beaudoin, 1998; Wolfe et al., 2001) and in southern Alberta (Case and Macdonald, 1995), with a "prolonged absence of wet years around 1700" on the eastern side of the Canadian prairies (St. George et al., 2009).

Fire frequency and intensity depend on regional climatic and environmental influences, where vegetation type, temperature and precipitation are the most important factors. Vegetation distribution impacts levoglucosan emission factors (the amount per kilogram of burnt fuel) and combustion characteristics (smoldering versus flaming fires) (Simoneit et al., 1999; Engling et al., 2006). Large-scale variations in vegetation types likely do not cause the observed centennial oscillations, but may affect fire signatures over millennial timescales. Instead, elevated surface air temperatures and sustained drought affect fuel flammability and lead to increased global fire activity over seasonal to centennial timescales (Daniau et al., 2012). Warmer, drier summers and increased deadwood availability due to past fire suppression, as well as insect outbreaks (Kurz et al., 2008; Wolken et al., 2011), and increased tree mortality from drought (van Mantgem et al., 2009) may amplify current and future fires. Increasing forest mortality in a warming climate (Anderegg et al., 2013) results in greater fuel availability with the potential to intensify future boreal fire activity.

\subsubsection{Human impact on boreal fire activity}

Climate (droughts and temperatures) may be more important than anthropogenic activity in influencing high-latitude boreal fires in areas responsible for levoglucosan emissions reaching the Greenland Ice Sheet, even after 1750 CE (Marlon et al., 2008). Marlon et al. (2008) argue that population growth and land-cover conversion rates, along with increases in global temperatures, are the main factors for the sharp increase in global biomass burning from $1750 \mathrm{CE}$ to the late 19th century. In addition, Marlon et al. (2008) and Prentice (2010) assert that the expansion of agriculture and fire suppression since the early twentieth century resulted in decreased global fire activity. Pyrogenic methane isotopic data (Ferretti et al., 2005; Mischler et al., 2009) show relatively high values in the first millennium CE, but do not support the prominent maximum of an anthropogenic peak at $\sim 1900 \mathrm{CE}$ in the $\mathrm{HLNH}>55^{\circ} \mathrm{N} \mathrm{GCD}$ curve (Marlon et al., 2008) and inferred from CO isotopic measurements (Wang et al., 2010). Emissions modelling does not agree with methane isotopes data, and suggests that higher-than-present levels of pre-industrial biomass burning are implausible (van der Werf et al., 2013). Levoglucosan concentrations are relatively high during the past century, but other higher multi-decadal maxima are present in our data set (Supplement Fig. S5). The number of post-1950 CE samples in our data set is limited, and so the levoglucosan analyses in the past decades are not sufficient to clearly assess the 20th century downturn in fire activity, as inferred by Marlon et al. (2008) and Wang et al. (2010). In addition, levoglucosan data do not show the evident anthropogenic peak started from $1750 \mathrm{CE}$ as inferred from the GCD synthesis, as the NEEM levoglucosan concentrations are low until the beginning of the 20th century, followed by a modest concentration increase.

The differences between the GCD, $\delta^{13} \mathrm{C}_{\text {of }} \mathrm{CH}_{4}$, and levoglucosan in NEEM may be related to differing initiation times of extensive industrial and agricultural activity in boreal forest source regions. Population growth and major anthropogenic land clearing in boreal regions only significantly increased during the past century (Kawamura et al., 2012). The former Soviet Union experienced the highest forest clearing rates and eastward cropland expansion into southern Siberia between 1940 and 1960 CE, while the high Canadian land-clearing rates occurred in the prairie provinces between 1900 and 1920 CE (Ramankutty and Foley, 1999). NEEM levoglucosan peaks during the same time interval as these land-clearing estimates, while Canadian ice cores also show peak biomass burning from 1920 to $1940 \mathrm{CE}$ (Yalcin et al., 2006) and 1930-1980 CE (Whitlow et al., 1994).

The dense GCD sampling in North America and Europe may affect the high-latitude Northern Hemisphere charcoal synthesis. The conclusion that land-use and fire management practices have decreased global fire activity since the early 20th century (Marlon et al., 2008) may be more appropriate for temperate North America and Europe than for boreal regions. NEEM levoglucosan concentrations may instead reflect the boreal source region land clearance that was occurring even when anthropogenic land use and fire suppression were dominant in other parts of the Northern Hemisphere.

\section{Conclusions}

Levoglucosan, $\mathrm{NH}_{4}^{+}$and $\mathrm{BC}$ analyses in the NEEM ice cores provide a specific record of past biomass burning. Each biomass burning marker has a set of intrinsic strengths and limitations, and so a combination of fire proxies results in a more robust reconstruction. The NEEM records and connections with back trajectories and other palaeoclimate studies suggest North American/Canadian fires are the main sources of pyrogenic aerosols transported to the site, in particular during the pre-industrial period. However, Siberian forests may be an essential aspect of boreal fire reconstructions that have not yet been appropriately evaluated. 
Temperature is an important controlling factor of boreal fire activity on centennial timescales. On multi-decadal or shorter timescales, however, boreal fires may be mainly influenced by droughts. Our results demonstrate the greatest amount of decadal-scale fire activity during the mid-1600s. We suggest that the 1500-1700 CE maximum in fire activity is due to increased boreal forest fires, caused by extensive dry conditions in the Asian region. NEEM levoglucosan concentrations suggest the major drought centred on $1640 \mathrm{CE}$ may have been more extensive than inferred from local palaeoclimate reconstructions, and that this event dominates boreal fire activity over the past 2000 years. Fires are concurrent with known extensive droughts and monsoon failures, and levoglucosan concentrations during these droughts are greater than during the last 150 years when anthropogenic land-clearing rates were the highest in history. This evidence suggests that climate variability has influenced boreal forest fires more than anthropogenic activity over the past millennia in the boreal regions that supply biomass-burning-related species to Greenland. However, climate change and anthropogenic activity may increase future boreal fire activity, and have the potential to exceed the fire activity of the mid-1600s.

\section{The Supplement related to this article is available online at doi:10.5194/cp-10-1905-2014-supplement.}

Acknowledgements. NEEM is directed and organized by the Centre for Ice and Climate at the Niels Bohr Institute and US NSF, Office of Polar Programs. The research leading to these results has received funding from the European Union's Seventh Framework programme (FP7/2007-2013) under grant agreement no. 243908, "Past4Future. Climate change - Learning from the past climate", and is Past4Future contribution no. 70. The research leading to these results has received funding from the European Union's Seventh Framework programme ("Ideas" Specific Programme, ERC Advanced Grant) under grant agreement no. 267696 "EARLYhumanIMPACT". This is EarlyHumanImpact contribution no. 10. US NSF grant 0909541 supported collection and analysis of the NEEM-2011-S1 core. We acknowledge the substantial efforts of the NEEM logistics, drilling, and science trench teams for their substantial efforts during the collection of the NEEM-2011-S1 core, as well as the entire DRI ice core analytical team for their efforts in analysing the core. Financial support of the Swiss National Science Foundation is acknowledged (Simon Schüpbach). J. R. McConnell was supported by a United States National Science Foundation postdoctoral fellowship (EAR-0948288). We thank PAGES (Past Global Changes) for supporting the palaeofire studies' development. We also acknowledge Elga (High Wycombe, UK) for providing ultrapure water. We thank A. Eichler for the use of data extracted from Eichler et al. (2011), and O. Pechony and D. Shindell for the use of their data extracted from Pechony and Shindell (2010). We also thank Thomas Blunier and Jerome Chappellaz for the use of their high-resolution NEEM methane data.

Edited by: E. Wolff

\section{References}

Anderegg, W. R. L., Kane, J. M., and Anderegg, L. D. L.: Consequences of widespread tree Mortality triggered by drought and temperature stress, Nat. Clim. Chang., 3, 30-36, 2013.

Andersen, K. K., Ditlevsen, P. D., Rasmussen, S. O., Clausen, H. B., Vinther, B. M., Johnsen, S. J., and Steffensen, J. P.: Retrieving a common accumulation record from Greenland ice cores for the past 1800 years, J. Geophys. Res.-Atmos., 111, D15106, doi:10.1029/2005jd006765, 2006.

Andreae, M. O.: Soot Carbon and Excess Fine Potassium: LongRange Transport of Combustion-Derived Aerosols, Scence, 220, 1148-1151, 1983.

Andreev, A. A., Pierau, R., Kalugin, I. A., Daryin, A. V., Smolyaninova, L. G., and Diekmann, B.: Environmental changes in the northern Altai during the last millennium documented in Lake Teletskoye pollen record, Quat. Res., 67, 394-399, doi:10.1016/j.yqres.2006.11.004, 2007.

Banta, J. R., McConnell, J. R., Edwards, R., and Engelbrecht, J. P.: Delineation of carbonate dust, aluminous dust, and sea salt deposition in a Greenland glaciochemical array using positive matrix factorization, Geochem. Geophys. Geosyst., 9, Q07013, doi:10.1029/2007gc001908, 2008.

Battisti, D. S., and Naylor, R. L.: Historical Warnings of Future Food Insecurity with Unprecedented Seasonal Heat, Science, 323, 240-244, doi:10.1126/science.1164363, 2009.

Bauer, S. E., Bausch, A., Nazarenko, L., Tsigaridis, K., Xu, B. Q., Edwards, R., Bisiaux, M., and McConnell, J.: Historical and future black carbon deposition on the three ice caps: Ice core measurements and model simulations from 1850 to 2100, J. Geophys. Res.-Atmos., 118, 7948-7961, doi:10.1002/jgrd.50612, 2013.

Bjornstad, O. N., and Falck, W.: Nonparametric spatial covariance functions: Estimation and testing, Environ. Ecol. Stat., 8, 53-70, doi:10.1023/a:1009601932481, 2001.

Blunier, T., Spahni, R., Barnola, J.-M., Chappellaz, J., Loulergue, L., and Schwander, J.: Synchronization of ice core records via atmospheric gases, Clim. Past, 3, 325-330, doi:10.5194/cp3-325-2007, 2007.

Bory, A. J. M., Biscaye, P. E., Svensson, A., and Grousset, F. E.: Seasonal variability in the origin of recent atmospheric mineral dust at NorthGRIP, Greenland, Earth Planet. Sci. Lett., 196, 123134, doi:10.1016/s0012-821x(01)00609-4, 2002.

Bory, A. J. M., Biscaye, P. E., Piotrowski, A. M., and Steffensen, J. P.: Regional variability of ice core dust composition and provenance in Greenland, Geochem. Geophys. Geosyst., 4, 1107, doi:10.1029/2003gc000627, 2003.

Bowman, D., Balch, J. K., Artaxo, P., Bond, W. J., Carlson, J. M., Cochrane, M. A., D'Antonio, C. M., DeFries, R. S., Doyle, J. C., Harrison, S. P., Johnston, F. H., Keeley, J. E., Krawchuk, M. A., Kull, C. A., Marston, J. B., Moritz, M. A., Prentice, I. C., Roos, C. I., Scott, A. C., Swetnam, T. W., van der Werf, G. R., and Pyne, S. J.: Fire in the Earth System, Science, 324, 481-484, doi:10.1126/science.1163886, 2009.

Brunelle, A., Whitlock, C., Bartlein, P., and Kipfmueller, K.: Holocene fire and vegetation along environmental gradients in the Northern Rocky Mountains, Quat. Sci. Rev., 24, 2281-2300, doi:10.1016/j.quascirev.2005.11.010, 2005.

Canadian Forest Service: The State of Canada's Forests 2004-2005: The boreal forest, Ottawa, 2005. 
Case, R. A. and MacDonald, G. M.: A dendroclimatic reconstruction of annual precipitation on the Western Canadian Prairies since AD 1505 from pinus-flexilis james, Quaternary Res., 44, 267-275, doi:10.1006/qres.1995.1071, 1995.

Chen, F., Yuan, Y. J., Wen, W. S., Yu, S. L., Fan, Z., Zhang, R. B., Zhang, T. W., and Shang, H. M.: Tree-ring-based reconstruction of precipitation in the Changling Mountains, China, since A.D.1691, Int. J. Biometeorol., 56, 765-774, doi:10.1007/s00484-011-0431-8, 2012.

Chen, H. F., Song, S. R., Lee, T. Q., Lowemark, L., Chi, Z. Q., Wang, Y., and Hong, E.: A multiproxy lake record from Inner Mongolia displays a late Holocene teleconnection between central Asian and North Atlantic climates, Quat. Int., 227, 170-182, doi:10.1016/j.quaint.2010.03.005, 2010.

Christiansen, B., and Ljungqvist, F. C.: The extra-tropical Northern Hemisphere temperature in the last two millennia: reconstructions of low-frequency variability, Clim. Past., 8, 765-786, doi:10.5194/cp-8-765-2012, 2012.

Chu, G., Sun, Q., Wang, X., and Sun, J.: Snow anomaly events from historical documents in eastern China during the past two millennia and implication for low-frequency variability of AO/NAO and PDO, Geophys. Res. Lett., 35, L14806, doi:10.1029/2008g1034475, 2008.

Conard, S. G., Sukhinin, A. I., Stocks, B. J., Cahoon, D. R., Davidenko, E. P., and Ivanova, G. A.: Determining effects of area burned and fire severity on carbon cycling and emissions in Siberia, Clim. Change, 55, 197-211, doi:10.1023/a:1020207710195, 2002.

Conedera, M., Tinner, W., Neff, C., Meurer, M., Dickens, A. F., and Krebs, P.: Reconstructing past fire regimes: methods, applications, and relevance to fire management and conservation, Quat. Sci. Rev., 28, 555-576, doi:10.1016/j.quascirev.2008.11.005, 2009.

Cook, E. R., Woodhouse, C. A., Eakin, C. M., Meko, D. M., and Stahle, D. W.: Long-term aridity changes in the western United States, Science, 306, 1015-1018, doi:10.1126/science.1102586, 2004.

Cook, E. R., Anchukaitis, K. J., Buckley, B. M., D’Arrigo, R. D., Jacoby, G. C., and Wright, W. E.: Asian Monsoon Failure and Megadrought During the Last Millennium, Science, 328, 486489, doi:10.1126/science.1185188, 2010.

Crowley, T. J., and Lowery, T. S.: How warm was the medieval warm period?, Ambio, 29, 51-54, doi:10.1639/00447447(2000)029[0051:hwwtmw]2.0.co;2, 2000.

Damoah, R., Spichtinger, N., Forster, C., James, P., Mattis, I., Wandinger, U., Beirle, S., Wagner, T., and Stohl, A.: Around the world in 17 days - hemispheric-scale transport of forest fire smoke from Russia in May 2003, Atmos. Chem. Phys., 4, 13111321, doi:10.5194/acp-4-1311-2004, 2004.

Daniau, A. L., Harrison, S. P., and Bartlein, P. J.: Fire regimes during the Last Glacial, Quat. Sci. Rev., 29, 2918-2930, doi:10.1016/j.quascirev.2009.11.008, 2010.

Daniau, A. L., Bartlein, P. J., Harrison, S. P., Prentice, I. C., Brewer, S., Friedlingstein, P., Harrison-Prentice, T. I., Inoue, J., Izumi, K., Marlon, J. R., Mooney, S., Power, M. J., Stevenson, J., Tinner, W., Andrič, M., Atanassova, J., Behling, H., Black, M., Blarquez, O., Brown, K. J., Carcaillet, C., Colhoun, E. A., Colombaroli, D., Davis, B. A. S., D'Costa, D., Dodson, J., Dupont, L., Eshetu, Z., Gavin, D. G., Genries, A., Haberle, S.,
Hallett, D. J., Hope, G., Horn, S. P., Kassa, T. G., Katamura, F., Kennedy, L. M., Kershaw, P., Krivonogov, S., Long, C., Magri, D., Marinova, E., McKenzie, G. M., Moreno, P. I., Moss, P., Neumann, F. H., Norstroöm, E., Paitre, C., Rius, D., Roberts, N., Robinson, G. S., Sasaki, N., Scott, L., Takahara, H., Terwilliger, V., Thevenon, F., Turner, R., Valsecchi, V. G., Vannière, B., Walsh, M., Williams, N., and Zhang, Y.: Predictability of biomass burning in response to climate changes, Global Biogeochem. Cy., 26, GB4007, doi:10.1029/2011GB004249, 2012.

Davi, N., Jacoby, G., Fang, K., Li, J., D’Arrigo, R., Baatarbileg, N., and Robinson, D.: Reconstructing drought variability for Mongolia based on a large-scale tree ring network: 1520-1993, J. Geophys. Res.-Atmos., 115, D22103, doi:10.1029/2010jd013907, 2010.

de Groot, W. J., Cantin, A. S., Flannigan, M. D., Soja, A. J., Gowman, L. M., and Newbery, A.: A comparison of Canadian and Russian boreal forest fire regimes, For. Ecol. Manage., 294, 23 34, doi:10.1016/j.foreco.2012.07.033, 2013.

Dentener, F., Kinne, S., Bond, T., Boucher, O., Cofala, J., Generoso, S., Ginoux, P., Gong, S., Hoelzemann, J. J., Ito, A., Marelli, L., Penner, J. E., Putaud, J.-P., Textor, C., Schulz, M., van der Werf, G. R., and Wilson, J.: Emissions of primary aerosol and precursor gases in the years 2000 and 1750 prescribed data-sets for AeroCom, Atmos. Chem. Phys., 6, 43214344, doi:10.5194/acp-6-4321-2006, 2006.

Diamond, J. M.: Collapse: How Societies Choose to Fail Or Succeed, Viking, New York, 2005.

Dibb, J. E., Talbot, R. W., Whitlow, S. I., Shipham, M. C., Winterle, J., McConnell, J., and Bales, R.: Biomass burning signatures in the atmosphere and snow at Summit, Greenland: An event on 5 August 1994, Atmos. Environ., 30, 553-561, 1996.

Dronin, N. M., and Bellinger, E. G.: Climate Dependence and Food Problems in Russia, 1900-1990: The Interaction of Climate and Agricultural Policy and Their Effect on Food Problems, central European University Press, Budepest, Hungary, 2005.

Eichler, A., Tinner, W., Brusch, S., Olivier, S., Papina, T., and Schwikowski, M.: An ice-core based history of Siberian forest fires since AD 1250, Quat. Sci. Rev., 30, 1027-1034, doi:10.1016/j.quascirev.2011.02.007, 2011.

Engling, G., Carrico, C. M., Kreldenweis, S. M., Collett, J. L., Day, D. E., Malm, W. C., Lincoln, E., Hao, W. M., Iinuma, Y., and Herrmann, H.: Determination of levoglucosan in biomass combustion aerosol by high-performance anion-exchange chromatography with pulsed amperometric detection, Atmos. Environ., 40, S299-S311, doi:10.1016/j.atmosenv.2005.12.069, 2006.

Fang, K. Y., Davi, N., Gou, X. H., Chen, F. H., Cook, E., Li, J. B., and D'Arrigo, R.: Spatial drought reconstructions for central High Asia based on tree rings, Clim. Dyn., 35, 941-951, doi:10.1007/s00382-009-0739-9, 2010.

Fang, K. Y., Gou, X., Chen, F., Frank, D., Liu, C., Li, J., and Kazmer, M.: Precipitation variability during the past 400 years in the Xiaolong Mountain (central China) inferred from tree rings, Clim. Dyn., 39, 1697-1707, doi:10.1007/s00382-012-1371-7, 2012.

FAO: Fire management: Global assessment 2006, Food and Agriculture Organization of the United Nations, Rome, 2007. 
Feng, S., Hu, Q., and Oglesby, R. J.: Influence of Atlantic sea surface temperatures on persistent drought in North America, Clim. Dyn., 37, 569-586, doi:10.1007/s00382-010-0835-x, 2011.

Ferretti, D. F., Miller, J. B., White, J. W. C., Etheridge, D. M., Lassey, K. R., Lowe, D. C., Meure, C. M. M., Dreier, M. F., Trudinger, C. M., van Ommen, T. D., and Langenfelds, R. L.: Unexpected changes to the global methane budget over the past 2000 years, Science, 309, 1714-1717, doi:10.1126/science.1115193, 2005.

Fischer, H., Siggaard-Andersen, M. L., Ruth, U., Rothlisberger, R., and Wolff, E.: Glacial/interglacial changes in mineral dust and sea-salt records in polar ice cores: Sources, transport, and deposition, Rev. Geophys., 45, RG1002, doi:10.1029/2005rg000192, 2007.

Fischer, H., Behrens, M., Bock, M., Richter, U., Schmitt, J., Loulergue, L., Chappellaz, J., Spahni, R., Blunier, T., Leuenberger, M., and Stocker, T. F.: Changing boreal methane sources and constant biomass burning during the last termination, Nature, 452, 864-867, doi:10.1038/nature06825, 2008.

Flanner, M. G., Zender, C. S., Randerson, J. T., and Rasch, P. J.: Present-day climate forcing and response from black carbon in snow, J. Geophys. Res.-Atmos., 112, doi:10.1029/2006jd008003, 2007.

Fraser, M. P., and Lakshmanan, K.: Using levoglucosan as a molecular marker for the long-range transport of biomass combustion aerosols, Environ. Sci. Technol., 34, 4560-4564, doi:10.1021/es9912291, 2000.

Fuhrer, K., Neftel, A., Anklin, M., and Maggi, V.: continuous measurements of hydrogen-peroxide, formaldehyde, calcium and ammonium concentrations along the new grip ice core from summit, central greenland, Atmospheric Environment Part a-General Topics, 27, 1873-1880, doi:10.1016/09601686(93)90292-7, 1993.

Fuhrer, K., Neftel, A., Anklin, M., Staffelbach, T., and Legrand, M.: High-resolution ammonium ice core record covering a complete glacial-interglacial cycle, J. Geophys. Res.-Atmos., 101, 41474164, 1996.

Fuhrer, K., and Legrand, M.: Continental biogenic species in the Greenland Ice Core Project ice core: Tracing back the biomass history of the North American continent, J. Geophys. Res.Oceans, 102, 26735-26745, 1997.

Gambaro, A., Zangrando, R., Gabrielli, P., Barbante, C., and Cescon, P.: Direct determination of levoglucosan at the picogram per milliliter level in Antarctic ice by highperformance liquid chromatography/electrospray ionization triple quadrupole mass spectrometry, Anal. Chem., 80, 16491655, doi:10.1021/ac701655x, 2008.

Gao, S., Hegg, D. A., Hobbs, P. V., Kirchstetter, T. W., Magi, B. I., and Sadilek, M.: Water-soluble organic components in aerosols associated with savanna fires in southern Africa: Identification, evolution, and distribution, J. Geophys. Res.-Atmos., 108, 8491, doi:10.1029/2002jd002324, 2003.

Generoso, S., Bey, I., Attie, J. L., and Breon, F. M.: A satelliteand model-based assessment of the 2003 Russian fires: Impact on the Arctic region, J. Geophys. Res.-Atmos., 112, doi:10.1029/2006jd008344, 2007.

Goldberg, E. D.: Black carbon in the environment: properties and distribution, J. Wiley, New York, 1985.
Golubev, G., and Dronin, N. M.: Geography of Droughts and Food Problems in Russia (1900-2000). Report of the International Project on Global Environmental Change and Its Threat to Food and Water Security in Russia. Department of Geography, Moscow State University, Moscow, Russia, 2004.

Grove, R. H.: Global impact of the 1789-93 El Nino, Nature, 393, 318-319, doi:10.1038/30636, 1998.

Hallett, D. J., Lepofsky, D. S., Mathewes, R. W., and Lertzman, K. P.: 11000 years of fire history and climate in the mountain hemlock rain forests of southwestern British Columbia based on sedimentary charcoal, Can. J. For. Res.-Rev. Can. Rech. For., 33, 292-312, doi:10.1139/x02-177, 2003.

Hansen, J., and Nazarenko, L.: Soot climate forcing via snow and ice albedos, Proc. Natl. Acad. Sci. U. S. A., 101, 423-428, doi:10.1073/pnas.2237157100, 2004.

Hegg, D. A., Warren, S. G., Grenfell, T. C., Doherty, S. J., Larson, T. V., and Clarke, A. D.: Source Attribution of Black Carbon in Arctic Snow, Environ. Sci. Technol., 43, 4016-4021, doi:10.1021/es803623f, 2009.

Hennigan, C. J., Sullivan, A. P., Collett, J. L., and Robinson, A. L.: Levoglucosan stability in biomass burning particles exposed to hydroxyl radicals, Geophys. Res. Lett., 37, L09806, doi:10.1029/2010g1043088, 2010.

Herron, M. M., and Langway Jr, C. C.: Firn densification: an empirical model, J. Glaciol., 25, 373-385, 1980.

Hiller, A., Boettger, T., and Kremenetski, C.: Mediaeval climatic warming recorded by radiocarbon dated alpine tree-line shift on the Kola Peninsula, Russia, Holocene, 11, 491-497, doi:10.1191/095968301678302931, 2001.

Hodzic, A., Madronich, S., Bohn, B., Massie, S., Menut, L., and Wiedinmyer, C.: Wildfire particulate matter in Europe during summer 2003: meso-scale modeling of smoke emissions, transport and radiative effects, Atmos. Chem. Phys., 7, 4043-4064, doi:10.5194/acp-7-4043-2007, 2007.

Hoffmann, D., Tilgner, A., Iinuma, Y., and Herrmann, H.: Atmospheric Stability of Levoglucosan: A Detailed Laboratory and Modeling Study, Environ. Sci. Technol., 44, 694-699, doi:10.1021/es902476f, 2010.

Holmes, B. J., and Petrucci, G. A.: Water-soluble oligomer formation from acid-catalyzed reactions of levoglucosan in proxies of atmospheric aqueous aerosols, Environ. Sci. Technol., 40, 4983 4989, doi:10.1021/es060646c, 2006.

Holmes, B. J. and Petrucci, G. A.: Oligomerization of levoglucosan by Fenton chemistry in proxies of biomass burning aerosols, J. Atmos. Chem., 58, 151-166, doi:10.1007/s10874-007-9084-8, 2007.

Iinuma, Y., Bruggemann, E., Gnauk, T., Muller, K., Andreae, M. O., Helas, G., Parmar, R., and Herrmann, H.: Source characterization of biomass burning particles: The combustion of selected European conifers, African hardwood, savanna grass, and German and Indonesian peat, J. Geophys. Res.-Atmos., 112, D08209, doi:10.1029/2006jd007120, 2007.

IPCC: Climate Change 2013: The Scientific Basis. Contribution of Working Group I to the Fifth Assessment Report of the Intergovern- mental Panel on Climate Change, edited by: Stocker, T. F., Qin, D., Plattner, G.-K., Tignor, M., Allen, S. K., Boschung, J., Nauels, A., Xia, Y., Bex, V., and Midgley, P. M., 2013. 
Jacobson, M. Z.: The short-term cooling but long-term global warming due to biomass burning, J. Clim., 17, 2909-2926, doi:10.1175/1520-0442(2004)017<2909:tscblg>2.0.co;2, 2004.

Jaffrezo, J. L., Calas, T., and Bouchet, M.: Carboxylic acids measurements with ionic chromatography, Atmos. Environ., 32, 2705-2708, 1998.

Kahl, J. D. W., Martinez, D. A., Kuhns, H., Davidson, C. I., Jaffrezo, J. L., and Harris, J. M.: Air mass trajectories to Summit, Greenland: A 44-year climatology and some episodic events, J. Geophys. Res.-Oceans, 102, 26861-26875, doi:10.1029/97jc00296, 1997.

Kaplan, J. O., Krumhardt, K. M., Ellis, E. C., Ruddiman, W. F., Lemmen, C., and Goldewijk, K. K.: Holocene carbon emissions as a result of anthropogenic land cover change, Holocene, 21, 775-791, doi:10.1177/0959683610386983, 2011.

Kaufmann, P. R., Federer, U., Hutterli, M. A., Bigler, M., Schupbach, S., Ruth, U., Schmitt, J., and Stocker, T. F.: An Improved Continuous Flow Analysis System for High-Resolution Field Measurements on Ice Cores, Environ. Sci. Technol., 42, 8044 8050, doi:10.1021/es8007722, 2008.

Kawamura, K., Yokoyama, K., Fujii, Y., and Watanabe, O.: A Greenland ice core record of low molecular weight dicarboxylic acids, ketocarboxylic acids, and alpha-dicarbonyls: A trend from Little Ice Age to the present (1540 to 1989 AD), J. Geophys. Res.-Atmos., 106, 1331-1345, 2001.

Kawamura, K., Izawa, Y., Mochida, M., and Shiraiwa, T.: Ice core records of biomass burning tracers (levoglucosan and dehydroabietic, vanillic and p-hydroxybenzoic acids) and total organic carbon for past 300 years in the Kamchatka Peninsula, Northeast Asia, Geochim. Cosmochim. Acta, 99, 317-329, doi:10.1016/j.gca.2012.08.006, 2012.

Kehrwald, N., Zangrando, R., Gabrielli, P., Jaffrezo, J. L., Boutron, C., Barbante, C., and Gambaro, A.: Levoglucosan as a specific marker of fire events in Greenland snow, Tellus B., 64, 18196, doi:10.3402/tellusb.v64i0.18196, 2012.

Kuo, L. J., Herbert, B. E., and Louchouarn, P.: Can levoglucosan be used to characterize and quantify char/charcoal black carbon in environmental media?, Org. Geochem., 39, 1466-1478, doi:10.1016/j.orggeochem.2008.04.026, 2008.

Kurz, W. A., Stinson, G., Rampley, G. J., Dymond, C. C., and Neilson, E. T.: Risk of natural disturbances makes future contribution of Canada's forests to the global carbon cycle highly uncerain, Proc. Natl. Acad. Sci. USA, 105, 1551-1555, doi:10.1073/pnas.0708133105, 2008.

Lavoue, D., Liousse, C., Cachier, H., Stocks, B. J., and Goldammer, J. G.: Modeling of carbonaceous particles emitted by boreal and temperate wildfires at northern latitudes, J. Geophys. Res.Atmos., 105, 26871-26890, doi:10.1029/2000jd900180, 2000.

Legrand, M., De Angelis, M., Staffelbach, T., Neftel, A., and Stauffer, B.: Large perturbation of ammonium and organic-acids content in the Summit-Greenland ice core - Fingerprint from forestfires, Geophys. Res. Lett., 19, 473-475, 1992.

Legrand, M., Angelis, M., Cachier, H., and Gaudichet, A.: Boreal Biomass Burning Over the Last 80 Years Recorded in a SummitGreenland Ice Core, in: Ice Core Studies of Global Biogeochemical Cycles, edited by: Delmas, R., NATO ASI Series, Springer Berlin Heidelberg, 347-360, 1995.

Legrand, M., and DeAngelis, M.: Light carboxylic acids in Greenland ice: A record of past forest fires and vegetation emissions from the boreal zone, J. Geophys. Res.-Atmos., 101, 4129-4145, 1996.

Legrand, M. and Mayewski, P.: Glaciochemistry of polar ice cores: A review, Rev. Geophys., 35, 219-243, 1997.

Li, J. B., Cook, E. R., Chen, F. H., Davi, N., D’Arrigo, R., Gou, X. H., Wright, W. E., Fang, K. Y., Jin, L. Y., Shi, J. F., and Yang, T.: Summer monsoon moisture variability over China and Mongolia during the past four centuries, Geophys. Res. Lett., 36, L22705, doi:10.1029/2009g1041162, 2009.

Liu, Y., Shi, J. F., Shishov, V., Vaganov, E., Yang, Y. K., Cai, Q. F., Sun, J. Y., Wang, L., and Djanseitov, I.: Reconstruction of MayJuly precipitation in the north Helan Mountain, Inner Mongolia since AD 1726 from tree-ring late-wood widths, Chin. Sci. Bull., 49, 405-409, doi:10.1007/BF02900325, 2004.

Liu, Y., Tian, H., Song, H. M., and Liang, J. M.: Tree ring precipitation reconstruction in the Chifeng-Weichang region, China, and East Asian summer monsoon variation since AD 1777, J. Geophys. Res.-Atmos., 115, D06103, doi:10.1029/2009jd012330, 2010.

Lupker, M., Aciego, S. M., Bourdon, B., Schwander, J., and Stocker, T. F.: Isotopic tracing ( $\mathrm{Sr}, \mathrm{Nd}, \mathrm{U}$ and $\mathrm{Hf})$ of continental and marine aerosols in an 18th century section of the Dye3 ice core (Greenland), Earth Planet. Sci. Lett., 295, 277-286, doi:10.1016/j.epsl.2010.04.010, 2010.

Mann, M. E., Zhang, Z. H., Hughes, M. K., Bradley, R. S., Miller, S. K., Rutherford, S., and Ni, F. B.: Proxy-based reconstructions of hemispheric and global surface temperature variations over the past two millennia, Proc. Natl. Acad. Sci. USA., 105, 1325213257, doi:10.1073/pnas.0805721105, 2008.

Mann, M. E., Zhang, Z. H., Rutherford, S., Bradley, R. S., Hughes, M. K., Shindell, D., Ammann, C., Faluvegi, G., and Ni, F. B.: Global Signatures and Dynamical Origins of the Little Ice Age and Medieval Climate Anomaly, Science, 326, 1256-1260, doi:10.1126/science.1177303, 2009.

Marlon, J. R., Bartlein, P. J., Carcaillet, C., Gavin, D. G., Harrison, S. P., Higuera, P. E., Joos, F., Power, M. J., and Prentice, I. C.: Climate and human influences on global biomass burning over the past two millennia, Nat. Geosci., 1, 697-702, doi:10.1038/ngeo313, 2008.

Marlon, J. R., Bartlein, P. J., Gavin, D. G., Long, C. J., Anderson, R. S., Briles, C. E., Brown, K. J., Colombaroli, D., Hallett, D. J., Power, M. J., Scharf, E. A., and Walsh, M. K.: Long-term perspective on wildfires in the western USA, Proc. Natl. Acad. Sci. USA., 109, E535-E543, doi:10.1073/pnas.1112839109, 2012.

Marlon, J. R., Bartlein, P. J., Daniau, A. L., Harrison, S. P., Maezumi, S. Y., Power, M. J., Tinner, W., and Vanniere, B.: Global biomass burning: a synthesis and review of Holocene paleofire records and their controls, Quat. Sci. Rev., 65, 5-25, doi:10.1016/j.quascirev.2012.11.029, 2013.

Masiello, C. A.: New directions in black carbon organic geochemistry, Mar. Chem., 92, 201-213, doi:10.1016/j.marchem.2004.06.043, 2004.

McConnell, J. R.: Continuous ice-core chemical analyses using inductively Coupled Plasma Mass Spectrometry, Environ. Sci. Technol., 36, 7-11, doi:10.1021/es011088z, 2002.

McConnell, J. R., Edwards, R., Kok, G. L., Flanner, M. G., Zender, C. S., Saltzman, E. S., Banta, J. R., Pasteris, D. R., Carter, M. M., and Kahl, J. D. W.: 20th-century industrial black carbon emis- 
sions altered arctic climate forcing, Science, 317, 1381-1384, doi:10.1126/science.1144856, 2007.

McConnell, J. R., and Edwards, R.: Coal burning leaves toxic heavy metal legacy in the Arctic, Proc. Natl. Acad. Sci. USA., 105, 12140-12144, doi:10.1073/pnas.0803564105, 2008.

McConnell, J. R.: New Directions: Historical black carbon and other ice core aerosol records in the Arctic for GCM evaluation, Atmos. Environ., 44, 2665-2666, doi:10.1016/j.atmosenv.2010.04.004, 2010.

McWethy, D. B., Whitlock, C., Wilmshurst, J. M., McGlone, M. S., and Li, X.: Rapid deforestation of South Island, New Zealand, by early Polynesian fires, Holocene, 19, 883-897, doi:10.1177/0959683609336563, 2009.

Melott, A. L., Thomas, B. C., Dreschhoff, G., and Johnson, C. K.: Cometary airbursts and atmospheric chemistry: Tunguska and a candidate Younger Dryas event, Geology, 38, 355-358, doi:10.1130/g30508.1, 2010.

Mischler, J. A., Sowers, T. A., Alley, R. B., Battle, M., McConnell, J. R., Mitchell, L., Popp, T., Sofen, E., and Spencer, M. K.: Carbon and hydrogen isotopic composition of methane over the last 1000 years, Glob. Biogeochem. Cycle, 23, GB4024, doi:10.1029/2009gb003460, 2009.

Moberg, A., Sonechkin, D. M., Holmgren, K., Datsenko, N. M., and Karlen, W.: Highly variable Northern Hemisphere temperatures reconstructed from low- and high-resolution proxy data, Nature, 433, 613-617, doi:10.1038/nature03265, 2005.

Mochida, M., Kawamura, K., Fu, P. Q., and Takemura, T.: Seasonal variation of levoglucosan in aerosols over the western North Pacific and its assessment as a biomass-burning tracer, Atmos. Environ., 44, 3511-3518, doi:10.1016/j.atmosenv.2010.06.017, 2010.

O’Brien, S. R., Mayewski, P. A., Meeker, L. D., Meese, D. A., Twickler, M. S., and Whitlow, S. I.: Complexity of holocene climate as reconstructed from a Greenland ice core, Science, 270, 1962-1964, doi:10.1126/science.270.5244.1962, 1995.

Oros, D. R., and Simoneit, B. R. T.: Identification and emission factors of molecular tracers in organic aerosols from biomass burning Part 2. Deciduous trees, Appl. Geochem., 16, 1545-1565, doi:10.1016/s0883-2927(01)00022-1, 2001a.

Oros, D. R., and Simoneit, B. R. T.: Identification and emission factors of molecular tracers in organic aerosols from biomass burning Part 1. Temperate climate conifers, Appl. Geochem., 16, 1513-1544, doi:10.1016/s0883-2927(01)00021-x, 2001b.

Pages 2k: Continental-scale temperature variability during the past two millennia, Nat. Geosci., 6, 339-346, doi:10.1038/ngeo1797, 2013.

Paris, J.-D., Stohl, A., Nédélec, P., Arshinov, M. Yu., Panchenko, M. V., Shmargunov, V. P., Law, K. S., Belan, B. D., and Ciais, P.: Wildfire smoke in the Siberian Arctic in summer: source characterization and plume evolution from airborne measurements, Atmos. Chem. Phys., 9, 9315-9327, doi:10.5194/acp-9-9315-2009, 2009.

Pechony, O. and Shindell, D. T.: Driving forces of global wildfires over the past millennium and the forthcoming century, Proc. Natl. Acad. Sci. USA, 107, 19167-19170, doi:10.1073/pnas.1003669107, 2010.

Pederson, N., Jacoby, G. C., D’Arrigo, R. D., Cook, E. R., Buckley, B. M., Dugarjav, C., and Mijiddorj, R.: Hydrometeorological reconstructions for northeastern Mongolia derived from tree rings: 1651-1995, J. Clim., 14, 872-881, doi:10.1175/15200442(2001)014<0872:hrfnmd>2.0.co;2, 2001.

Power, M. J., Marlon, J., Ortiz, N., Bartlein, P. J., Harrison, S. P., Mayle, F. E., Ballouche, A., Bradshaw, R. H. W., Carcaillet, C., Cordova, C., Mooney, S., Moreno, P. I., Prentice, I. C., Thonicke, K., Tinner, W., Whitlock, C., Zhang, Y., Zhao, Y., Ali, A. A., Anderson, R. S., Beer, R., Behling, H., Briles, C., Brown, K. J., Brunelle, A., Bush, M., Camill, P., Chu, G. Q., Clark, J., Colombaroli, D., Connor, S., Daniau, A. L., Daniels, M., Dodson, J., Doughty, E., Edwards, M. E., Finsinger, W., Foster, D., Frechette, J., Gaillard, M. J., Gavin, D. G., Gobet, E., Haberle, S., Hallett, D. J., Higuera, P., Hope, G., Horn, S., Inoue, J., Kaltenrieder, P., Kennedy, L., Kong, Z. C., Larsen, C., Long, C. J., Lynch, J., Lynch, E. A., McGlone, M., Meeks, S., Mensing, S., Meyer, G., Minckley, T., Mohr, J., Nelson, D. M., New, J., Newnham, R., Noti, R., Oswald, W., Pierce, J., Richard, P. J. H., Rowe, C., Goni, M. F. S., Shuman, B. N., Takahara, H., Toney, J., Turney, C., Urrego-Sanchez, D. H., Umbanhowar, C., Vandergoes, M., Vanniere, B., Vescovi, E., Walsh, M., Wang, X., Williams, N., Wilmshurst, J., and Zhang, J. H.: Changes in fire regimes since the Last Glacial Maximum: an assessment based on a global synthesis and analysis of charcoal data, Clim. Dyn., 30, 887-907, doi:10.1007/s00382-007-0334-x, 2008.

Power, M. J., Marlon, J. R., Bartlein, P. J., and Harrison, S. P.: Fire history and the Global Charcoal Database: A new tool for hypothesis testing and data exploration, Paleogeogr. Paleoclimatol. Paleoecol., 291, 52-59, doi:10.1016/j.palaeo.2009.09.014, 2010.

Prentice, I. C.: The Burning Issue, Science, 330, 1636-1637, doi:10.1126/science.1199809, 2010.

Preston, C. M. and Schmidt, M. W. I.: Black (pyrogenic) carbon: a synthesis of current knowledge and uncertainties with special consideration of boreal regions, Biogeosciences, 3, 397-420, doi:10.5194/bg-3-397-2006, 2006.

Pyne, S. J.: The fires this time, and next, Science, 294, 1005-1006, doi:10.1126/science.1064989, 2001.

Quinn, P. K., Bates, T. S., Baum, E., Doubleday, N., Fiore, A. M., Flanner, M., Fridlind, A., Garrett, T. J., Koch, D., Menon, S., Shindell, D., Stohl, A., and Warren, S. G.: Short-lived pollutants in the Arctic: their climate impact and possible mitigation strategies, Atmos. Chem. Phys., 8, 1723-1735, doi:10.5194/acp8-1723-2008, 2008.

Ramanathan, V., and Carmichael, G.: Global and regional climate changes due to black carbon, Nat. Geosci., 1, 221-227, doi:10.1038/ngeo156, 2008.

Ramankutty, N., and Foley, J. A.: Estimating historical changes in global land cover: Croplands from 1700 to 1992, Glob. Biogeochem. Cycle, 13, 997-1027, doi:10.1029/1999gb900046, 1999.

Randerson, J. T., Liu, H., Flanner, M. G., Chambers, S. D., Jin, Y., Hess, P. G., Pfister, G., Mack, M. C., Treseder, K. K., Welp, L. R., Chapin, F. S., Harden, J. W., Goulden, M. L., Lyons, E., Neff, J. C., Schuur, E. A. G., and Zender, C. S.: The impact of boreal forest fire on climate warming, Science, 314, 1130-1132, doi:10.1126/science.1132075, 2006.

Rasmussen, S. O., Abbott, P., Blunier, T., Bourne, A., Brook, E., Buchardt, S. L., Buizert, C., Chappellaz, J., Clausen, H. B., Cook, E., Dahl-Jensen, D., Davies, S., Guillevic, M., Kipfstuhl, S., Laepple, T., Seierstad, I. K., Severinghaus, J. P., Steffensen, J. P., Stowasser, C., Svensson, A., Vallelonga, P., Vinther, B. M., Wil- 
helms, F., and Winstrup, M.: A first chronology for the NEEM ice core, Clim. Past Discuss., 9, 2967-3013, doi:10.5194/cpd-92967-2013, 2013.

Rehfeld, K., Marwan, N., Heitzig, J., and Kurths, J.: Comparison of correlation analysis techniques for irregularly sampled time series, Nonlinear Process Geophys., 18, 389-404, doi:10.5194/npg-18-389-2011, 2011.

Ruddiman, W. F.: The anthropogenic greenhouse era began thousands of years ago, Clim. Change, 61, 261-293, doi:10.1023/B:CLIM.0000004577.17928.fa, 2003.

Running, S. W.: Is global warming causing more, larger wildfires?, Science, 313, 927-928, doi:10.1126/science.1130370, 2006.

Ruth, U., Wagenbach, D., Steffensen, J. P., and Bigler, M.: Continuous record of microparticle concentration and size distribution in the central Greenland NGRIP ice core during the last glacial period, J. Geophys. Res.-Atmos., 108, doi:10.1029/2002jd002376, 2003.

Sapart, C. J., Monteil, G., Prokopiou, M., van de Wal, R. S. W., Kaplan, J. O., Sperlich, P., Krumhardt, K. M., van der Veen, C., Houweling, S., Krol, M. C., Blunier, T., Sowers, T., Martinerie, P., Witrant, E., Dahl-Jensen, D., and Rockmann, T.: Natural and anthropogenic variations in methane sources during the past two millennia, Nature, 490, 85-88, 2012.

Sauchyn, D. J., and Beaudoin, A. B.: Recent environmental change in the southwestern Canadian Plains, Can. Geogr.-Geogr. Can., 42, 337-353, doi:10.1111/j.1541-0064.1998.tb01350.x, 1998.

Sauchyn, D. J., and Skinner, W. R.: A Proxy Record of Drought Severity for the Southwestern Canadian Plains, Canadian Water Resources Journal, 26, 253-272, doi:10.4296/cwrj2602253, 2001.

Savarino, J., and Legrand, M.: High northern latitude forest fires and vegetation emissions over the last millennium inferred from the chemistry of a central Greenland ice core, J. Geophys. Res.Atmos., 103, 8267-8279, 1998.

Shen, C., Wang, W.-C., Hao, Z., and Gong, W.: Exceptional drought events over eastern China during the last five centuries, Clim. Change, 85, 453-471, doi:10.1007/s 10584-007-9283-y, 2007.

Shindell, D. T., Chin, M., Dentener, F., Doherty, R. M., Faluvegi, G., Fiore, A. M., Hess, P., Koch, D. M., MacKenzie, I. A., Sanderson, M. G., Schultz, M. G., Schulz, M., Stevenson, D. S., Teich, H., Textor, C., Wild, O., Bergmann, D. J., Bey, I., Bian, H., Cuvelier, C., Duncan, B. N., Folberth, G., Horowitz, L. W., Jonson, J., Kaminski, J. W., Marmer, E., Park, R., Pringle, K. J., Schroeder, S., Szopa, S., Takemura, T., Zeng, G., Keating, T. J., and Zuber, A.: A multi-model assessment of pollution transport to the Arctic, Atmos. Chem. Phys., 8, 5353-5372, doi:10.5194/acp-85353-2008, 2008.

Sigl, M., McConnell, J. R., Layman, L., Maselli, O., McGwire, K., Pasteris, D., Dahl-Jensen, D., Steffensen, J. P., Vinther, B., Edwards, R., Mulvaney, R., and Kipfstuhl, S.: A new bipolar ice core record of volcanism from WAIS Divide and NEEM and implications for climate forcing of the last 2000 years, J. Geophys. Res.-Atmos., 118, 1151-1169, doi:10.1029/2012jd018603, 2013.

Simoneit, B. R. T., Schauer, J. J., Nolte, C. G., Oros, D. R., Elias, V. O., Fraser, M. P., Rogge, W. F., and Cass, G. R.: Levoglucosan, a tracer for cellulose in biomass burning and atmospheric particles, Atmos. Environ., 33, 173-182, 1999.
Simoneit, B. R. T.: Biomass burning - A review of organic tracers for smoke from incomplete combustion, Appl. Geochem., 17, 129-162, 2002.

St. George, S. S., Meko, D. M., Girardin, M. P., MacDonald, G. M., Nielsen, E., Pederson, G. T., Sauchyn, D. J., Tardif, J. C., and Watson, E.: The Tree-Ring Record of Drought on the Canadian Prairies, J. Clim., 22, 689-710, doi:10.1175/2008jcli2441.1, 2009.

Stahle, D. W., Cook, E. R., Cleaveland, M. K., Therrell, M. D., Meko, D. M., Grissino-Mayer, H. D., Watson, E., and Luckman, B. H.: Tree-ring data document 16 th century megadrought over North America, Eos, Transactions American Geophysical Union, 81, 121-125, doi:10.1029/00eo00076, 2000.

Stohl, A.: Characteristics of atmospheric transport into the Arctic troposphere, J. Geophys. Res.-Atmos., 111, doi:10.1029/2005jd006888, 2006.

Stohl, A., Andrews, E., Burkhart, J. F., Forster, C., Herber, A., Hoch, S. W., Kowal, D., Lunder, C., Mefford, T., Ogren, J. A., Sharma, S., Spichtinger, N., Stebel, K., Stone, R., Strom, J., Torseth, K., Wehrli, C., and Yttri, K. E.: Pan-Arctic enhancements of light absorbing aerosol concentrations due to North American boreal forest fires during summer 2004, J. Geophys. Res.-Atmos., 111, doi:10.1029/2006jd007216, 2006.

Tan, M., Liu, T. S., Hou, J. Z., Qin, X. G., Zhang, H. C., and Li, T. Y.: Cyclic rapid warming on centennial-scale revealed by a 2650 year stalagmite record of warm season temperature, Geophys. Res. Lett., 30, 1617, doi:10.1029/2003g1017352, 2003.

Taylor, K. C., Mayewski, P. A., Twickler, M. S., and Whitlow, S. I.: Biomass burning recorded in the GISP2 ice core: A record from eastern Canada?, Holocene, 6, 1-6, 1996.

The New York Times: Smoke shrouds Moskow as peat-bog fire rages, Aug. 09 1972, New York.

The Palm Beach Post: Thousands fight Russia Peat fire, Aug. 09 1972.

Thompson, L. G., Yao, T., Mosley-Thompson, E., Davis, M. E., Henderson, K. A., and Lin, P. N.: A high-resolution millennial record of the South Asian Monsoon from Himalayan ice cores, Science, 289, 1916-1919, doi:10.1126/science.289.5486.1916, 2000.

Trentmann, J., Luderer, G., Winterrath, T., Fromm, M. D., Servranckx, R., Textor, C., Herzog, M., Graf, H.-F., and Andreae, M. O.: Modeling of biomass smoke injection into the lower stratosphere by a large forest fire (Part I): reference simulation, Atmos. Chem. Phys., 6, 5247-5260, doi:10.5194/acp-65247-2006, 2006.

Turquety, S., Logan, J. A., Jacob, D. J., Hudman, R. C., Leung, F. Y., Heald, C. L., Yantosca, R. M., Wu, S. L., Emmons, L. K., Edwards, D. P., and Sachse, G. W.: Inventory of boreal fire emissions for North America in 2004: Importance of peat burning and pyroconvective injection, J. Geophys. Res.-Atmos., 112, doi:10.1029/2006jd007281, 2007.

van der Werf, G. R., Randerson, J. T., Collatz, G. J., Giglio, L., Kasibhatla, P. S., Arellano, A. F., Olsen, S. C., and Kasischke, E. S.: Continental-scale partitioning of fire emissions during the 1997 to 2001 El Nino/La Nina period, Science, 303, 73-76, doi:10.1126/science.1090753, 2004.

van der Werf, G. R., Peters, W., van Leeuwen, T. T., and Giglio, L.: What could have caused pre-industrial biomass burning 
emissions to exceed current rates?, Clim. Past, 9, 289-306, doi:10.5194/cp-9-289-2013, 2013.

van Mantgem, P. J., Stephenson, N. L., Byrne, J. C., Daniels, L. D., Franklin, J. F., Fule, P. Z., Harmon, M. E., Larson, A. J., Smith, J. M., Taylor, A. H., and Veblen, T. T.: Widespread Increase of Tree Mortality Rates in the Western United States, Science, 323, 521-524, doi:10.1126/science.1165000, 2009.

Vinther, B. M., Clausen, H. B., Johnsen, S. J., Rasmussen, S. O., Andersen, K. K., Buchardt, S. L., Dahl-Jensen, D., Seierstad, I. K., Siggaard-Andersen, M. L., Steffensen, J. P., Svensson, A., Olsen, J., and Heinemeier, J.: A synchronized dating of three Greenland ice cores throughout the Holocene, J. Geophys. Res.Atmos., 111, D13102, doi:10.1029/2005jd006921, 2006.

Wang, Z., Chappellaz, J., Park, K., and Mak, J. E.: Large Variations in Southern Hemisphere Biomass Burning During the Last 650 Years, Science, 330, 1663-1666, doi:10.1126/science.1197257, 2010.

Wang, Z.-h., Chen, Z.-y., Kou, Y., and Chen, Y.: Dry/Wet climate change since 960 A. D. in taihu drainage basin of China, Chin. Geograph.Sc., 11, 343-349, doi:10.1007/s11769-001-0050-0, 2001.

Wanner, H., Beer, J., Butikofer, J., Crowley, T. J., Cubasch, U., Fluckiger, J., Goosse, H., Grosjean, M., Joos, F., Kaplan, J. O., Kuttel, M., Muller, S. A., Prentice, I. C., Solomina, O., Stocker, T. F., Tarasov, P., Wagner, M., and Widmann, M.: Mid- to Late Holocene climate change: an overview, Quat. Sci. Rev., 27, 1791-1828, doi:10.1016/j.quascirev.2008.06.013, 2008.

Ward, D. S., Kloster, S., Mahowald, N. M., Rogers, B. M., Randerson, J. T., and Hess, P. G.: The changing radiative forcing of fires: global model estimates for past, present and future, Atmos. Chem. Phys., 12, 10857-10886, doi:10.5194/acp12-10857-2012, 2012.

Weimer, S., Alfarra, M. R., Schreiber, D., Mohr, M., Prévôt, A. S. H., and Baltensperger, U.: Organic aerosol mass spectral signatures from wood-burning emissions: Influence of burning conditions and wood type, J. Geophys. Res. Atmos., 113, D10304, doi:10.1029/2007jd009309, 2008.

Westerling, A. L., Hidalgo, H. G., Cayan, D. R., and Swetnam, T. W.: Warming and earlier spring increase western US forest wildfire activity, Science, 313, 940-943, doi:10.1126/science.1128834, 2006.

Whitlow, S., Mayewski, P., Dibb, J., Holdsworth, G., and Twickler, M.: An ice-core-based record of biomass burning in the arctic and sub-arctic, 1750-1980, Tellus B, 46, 234-242, 1994.

Wolfe, S. A., Huntley, D. J., David, P. P., Ollerhead, J., Sauchyn, D. J., and MacDonald, G. M.: Late 18th century drought-induced sand dune activity, Great Sand Hills, Saskatchewan, Can. J. Earth Sci., 38, 105-117, doi:10.1139/cjes-38-1-105, 2001.
Wolff, E. W., Barbante, C., Becagli, S., Bigler, M., Boutron, C. F., Castellano, E., de Angelis, M., Federer, U., Fischer, H., Fundel, F., Hansson, M., Hutterli, M., Jonsell, U., Karlin, T., Kaufmann, P., Lambert, F., Littot, G. C., Mulvaney, R., Rothlisberger, R., Ruth, U., Severi, M., Siggaard-Andersen, M. L., Sime, L. C., Steffensen, J. P., Stocker, T. F., Traversi, R., Twarloh, B., Udisti, R., Wagenbach, D., and Wegner, A.: Changes in environment over the last 800,000 years from chemical analysis of the EPICA Dome C ice core, Quat. Sci. Rev., 29, 285-295, doi:10.1016/j.quascirev.2009.06.013, 2010a.

Wolff, E. W., Chappellaz, J., Blunier, T., Rasmussen, S. O., and Svensson, A.: Millennial-scale variability during the last glacial: The ice core record, Quat. Sci. Rev., 29, 2828-2838, doi:10.1016/j.quascirev.2009.10.013, 2010b.

Wolken, J. M., Hollingsworth, T. N., Rupp, T. S., Chapin, F. S., Trainor, S. F., Barrett, T. M., Sullivan, P. F., McGuire, A. D., Euskirchen, E. S., Hennon, P. E., Beever, E. A., Conn, J. S., Crone, L. K., D’Amore, D. V., Fresco, N., Hanley, T. A., Kielland, K., Kruse, J. J., Patterson, T., Schuur, E. A. G., Verbyla, D. L., and Yarie, J.: Evidence and implications of recent and projected climate change in Alaska's forest ecosystems, Ecosphere, 2, art124, doi:10.1890/es11-00288.1, 2011.

Wooster, M. J., and Zhang, Y. H.: Boreal forest fires burn less intensely in Russia than in North America, Geophys. Res. Lett., 31, doi:10.1029/2004g1020805, 2004.

Yalcin, K., Wake, C. R., Kreutz, K. J., and Whitlow, S. I.: A 1000-yr record of forest fire activity from Eclipse Icefield, Yukon, Canada, Holocene, 16, 200-209, doi:10.1191/0959683606hl920rp, 2006.

Yang, B., Braeuning, A., Johnson, K. R., and Shi, Y. F.: General characteristics of temperature variation in China during the last two millennia, Geophys. Res. Lett., 29, 1324, doi:10.1029/2001g1014485, 2002.

Yang, B., Brauning, A., Zhang, Z., Dong, Z., and Esper, J.: Dust storm frequency and its relation to climate changes in Northern China during the past 1000 years, Atmos. Environ., 41, 92889299, doi:10.1016/j.atmosenv.2007.09.025, 2007.

Yao, P., Schwab, V. F., Roth, V., Xu, B., Yao, T., and Gleixner, G.: Levoglucosan concentrations in ice-core samples from the Tibetan Plateau determined by reverse-phase high-performance liquid chromatography-mass spectrometry, J. Glaciol., 59, 599608, 2013.

Zhang, P. Z., Cheng, H., Edwards, R. L., Chen, F. H., Wang, Y. J., Yang, X. L., Liu, J., Tan, M., Wang, X. F., Liu, J. H., An, C. L., Dai, Z. B., Zhou, J., Zhang, D. Z., Jia, J. H., Jin, L. Y., and Johnson, K. R.: A Test of Climate, Sun, and Culture Relationships from an 1810-Year Chinese Cave Record, Science, 322, 940-942, doi:10.1126/science.1163965, 2008.

Zhang, Y. H., Wooster, M. J., Tutubalina, O., and Perry, G. L. W.: Monthly burned area and forest fire carbon emission estimates for the Russian Federation from SPOT VGT, Remote Sens. Environ., 87, 1-15, doi:10.1016/s0034-4257(03)00141-x, 2003. 